NOTE

\title{
BEDTIME FOR [INDUSTRIAL DEVELOPMENT] BONDS?: MUNICIPAL BOND TAX LEGISLATION OF THE FIRST REAGAN ADMINISTRATION
}

\section{INTRODUCTION}

The term "municipal bonds" embraces several different types of debt instruments issued by a state or local government or by an agency or authority of such a government. Most obviously included are obligations issued by a state or local government to finance its own activities, usually capital construction. ${ }^{1}$ Such obligations, the interest on which is excluded from gross income under Internal Revenue Code section 103(a), are classified as "general obligations" if they are backed by the "full faith and credit" of the issuing government or as "revenue bonds" if instead they are supported by earmarked taxes or are secured by specific project revenues. ${ }^{2}$ Industrial Development Bonds (IDB's) are also a form of debt issued by a government agency or authority, but they differ from revenue bonds in that their principal user is a private person, typically a corporation, rather than the government or agency which issues the bonds. ${ }^{3}$ Interest on most IDB's is taxable, but certain categories of IDB's enjoy tax exemption under Code section 103(b). ${ }^{4}$ Mortgage Housing Subsidy Bonds (MHSB's) are a special kind of IDB for private homeowners that have, in recent years, received separate tax treatment under the provisions of Code section 103A. ${ }^{5}$ Additionally, student loan bonds, whose interest is exempt under Code section 103(a)(2), are

Copyright $\odot 1985$ by Law and Contemporary Problems

1. See, e.g., R. Robinson, Postwar Market for State and Local Government Securtties 37 (1960).

2. See, e.g., A. Rabinowitz, Municipal Bond Finance and Administration 33 (1969).

3. See id. For a discussion of IDB history and terminology, see infra notes 47-70 and accompanying text. "Principal user" is defined infra at note 82.

4. "Except as otherwise provided in this subsection, any industrial development bond shall be treated as an obligation not described in subsection (a)(1) or (2) [not excluded from gross income]." I.R.C. $\$ 103($ b)(1) (Lawyers Co-op. 1984). Exceptions are made for "exempt purpose" obligations, see id. \$103(b)(4), and for "certain small issues," see id. \$103(b)(6); see infra notes 71-85 and accompanying text.

5. This separate treatment was instituted in the Mortgage Subsidy Bond Tax Act of 1980, Pub. L. No. 96-499, \& 1103, 94 Stat. 2660, 2669 (codified as amended at I.R.C. $\$ \$ 103$ (b)(4)(A), (12), (13), 103A (Lawyers Co-op. 1984). DEFRA revived this section, which had lapsed on January 1, 1984, and extended it until December 31, 1987. Deficit Reduction Act of 1984, Pub. L. No. 98-369, \&611(a), 98 Stat. 494, 901 (codified at I.R.C. $\$ 103 \mathrm{~A}(\mathrm{c})(1)$ (B) (Lawyers Co-op. Supp. 1985). 
included along with IDB's and MHSB's in the category of "private activity bonds" whose interest is generally exempt from federal income tax to the recipient. ${ }^{6}$

This note is concerned with recent changes in the tax treatment of bonds whose interest is exempt under the provisions of section 103. In the past four years, three major tax acts have increasingly restricted both the demand and the supply of municipal obligations. In particular, they have curtailed the availability of tax-exempt bond financing for private industry and have imposed, on tax-exempt bonds generally, reporting requirements and other federal regulation which seems to have expanded both in scope and in complexity with each new piece of legislation.

The Economic Recovery Tax Act of 1981 (ERTA) ${ }^{7}$ instituted a number of major tax changes, including safe harbor leasing, ${ }^{8}$ Accelerated Cost Recovery System (ACRS), ${ }^{9}$ and especially reduction in tax rates, ${ }^{10}$ which can reasonably be expected to have important effects on the supply and, especially, the demand for state and local government bonds." ERTA contains only two provisions directly affecting municipal bonds, however, ${ }^{12}$ and these are of relatively minor importance. Major changes in section 103 were deferred until 1982, in light of other major tax changes requiring congressional attention in the 1981 Act. $^{13}$

The Tax Equity and Fiscal Responsibility Act of 1982 (TEFRA) ${ }^{14}$ introduced important revisions in section 103. These revisions, for the most part, reflect concern to correct perceived abuses resulting from excessive issuance of tax-exempt IDB's. ${ }^{15}$ TEFRA enacted public approval requirements for IDB's ${ }^{16}$ and a reporting requirement for all private activity tax-exempt bonds, ${ }^{17}$ shortened the maturity allowed on tax-exempt IDB's, ${ }^{18}$

6. Debt issued by charitable organizations exempt under I.R.C. $\$ 501$ (c)(3) (Lawyers Co-op. Supp. 1985) is also tax-exempt and is sometimes included in the category. See infra note 171 .

7. Pub. L. No. 97-34, 95 Stat. 172.

8. I.R.C. $\& 168(\mathrm{f})(8)$ (as amended) (Lawyers Co-op. Supp. 1985).

9. Id. $\$ \S 167(\mathrm{a}), 168$.

10. Id. $\$ 1$.

11. An investor's demand for tax-exempt securities is primarily determined by his tax bracket and by the yield available on alternative investments. See, e.g., D. OTt \& A. Meltzer, Federal TAx Treatment of State and Local Securities 24-30 (1963). If the after-tax return available on other investments increases, as it will as a result of each of the ERTA measures cited in the text, the demand for tax-exempt bonds can logically be expected to decline. See Arak \& Guentner, The Market for Tax-Exempt Issues: Why Are the Yields So High?, 36 NaT'L Tax J. 145, 153-58 (1983); Small-Issue Bond Users Protest Administration Proposals, 14 TAx Notes 779, 779 (1981) (Statement of A. Rivlin) (ACRS reduces need for firms to use tax-exempt IDB financing).

12. I.R.C. \& 103(b)(4)(I), (9)(i) (Lawyers Co-op. 1984); see infra notes 329-31, 355, and accompanying text.

13. See Kraft, Local Public Policy and Tax-Exempt Financing: Is Local Initiative Preempted by Federal Control?, 34 NAT'L TAX J. 373, 376-77 (1981).

14. Pub. L. No. 97-248, 96 Stat. 324.

15. See S. Rep. No. 494, 97th Cong., 2d Sess. 167-69, reprinted in 1982 U.S. Code Cong. \& AD. News 731, 929-31.

16. See infra notes $265-72$ and accompanying text.

17. See infra notes 107-13 and accompanying text.

18. See infra notes $\mathbf{2 8 7 - 9 8}$ and accompanying text. 
and restricted the availability of ACRS depreciation for facilities financed by them. ${ }^{19}$ Especially important was the treatment of "small issues," one of two major categories of tax-exempt IDB's. TEFRA immediately removed taxexemption for a number of these bonds ${ }^{20}$ and enacted sunset legislation eliminating the entire category from tax exemption after 1986.21

Title Six of the 1984 Deficit Reduction Act (DEFRA) ${ }^{22}$ is devoted entirely to tax-exempt obligations. In addition to a number of provisions relating to MHSB's, the Act's chief feature is imposition of an annual state-wide cap on tax-exempt private activity issuance. ${ }^{23}$ An additional cap is imposed on small issue IDB's, which are also further restricted and regulated. ${ }^{24}$ Like TEFRA, and perhaps even more obviously, DEFRA represents both a limitation on the volume of tax-exempt borrowing and an attempt to fine tune the use of taxexempt financing. Its provisions serving to curtail (yet, in a few instances, to expand) the issuance of tax-exempt debt are extremely specific and in places even, apparently, ad hoc, adding "yet another layer of complexity" to the already complicated area of tax-exempt finance. ${ }^{25}$

In part, the complexity of the TEFRA and DEFRA changes may reflect the legislative history of these enactments. TEFRA's municipal bond provisions originated in the Senate. ${ }^{26}$ Although the Administration later joined in supporting some of the measures enacted, ${ }^{27}$ the changes made by TEFRA are principally an expression of the preferences of the Senate Finance Committee. Its work, in effect, accomplished, the Senate showed little inclination after TEFRA for further radical change. Indeed, it seemed in some cases to be backing off from its previous position, notably in supporting a four year extension of the small issue exemption beyond its scheduled termination date. ${ }^{28}$ However, the Administration, which had initially been relatively uninvolved, ${ }^{29}$ by 1983 was supporting a volume cap or equivalent

19. See infra notes $\mathbf{2 7 3 - 8 5}$ and accompanying text.

20. See infra notes $\mathbf{1 2 2 - 4 7}$ and accompanying text.

21. See infra notes $114-21$ and accompanying text.

22. Pub. L. No. 98-369, $\$ \S 611-648,98$ Stat. 494, 901-41 (codified in scattered subsections of I.R.C. \$\$ 103, 103A (Lawyers Co-op. Supp. 1985)).

23. See infra notes $168-99$ and accompanying text.

24. See infra notes $\mathbf{1 3 5 - 4 7}$ and accompanying text.

25. Arkuss, Living with the Tax Reform Act, NAT'L L.J., Sept. 17, 1984, at 15, col. 1.

26. See H.R. Conf. Rep. No. 760, 97th Cong., 2d Sess. 579, reprinted in 1982 U.S. Code Cong. \& Ad. News 1190, 1295; S. Rep. No. 494, 97th Cong., 2d Sess. 174, reprinted in 1982 U.S. Code Conc. \& AD. News 731, 936.

27. On January 27, 1982, the Administration proposed curbs on the use of IDB's. See Gleckman, IDB Curbs Bared; Minimum Tax Seen on Bond Interest, BOND BUYER, Jan. 28, 1982, at 1 . The Administration proposed (1) that assets financed with tax-exempt bonds issued after 1982 be depreciated "using the straight-line method over an extended recovery period," (2) that tax-exempt financing be limited to bonds "that are publicly approved by local governments and which, after 1985 , receive a financial contribution or commitment from the local government," and (3) that small issue IDB's not be allowed for large businesses. Office of Management and Budget, Special ANALYsis G: TAX Expenditures 31-32 (1983).

28. See H.R. REP. No. 861, 98th Cong., 2d Sess. 1209-10, reprinted in 1984 U.S. Code Cong. \& AD. News, No. 6B, 751, 1203-04.

29. In 1981, the Reagan Administration temporarily adopted a hands-off policy regarding IDB's. Kraft, supra note 13, at 377. 
"comprehensive restrictions" on private activity borrowing. ${ }^{30}$ These views were espoused by the House Ways and Means Committee, which introduced the volume cap and most other limiting measures subsequently enacted into DEFRA. ${ }^{31}$

DEFRA, accordingly, represents not only an extension of previous legislation limiting the use of municipal bonds but a shift of origin from the Senate to the House and Administration, with concomitant changes in preference for various detailed aspects of municipal bond regulation. Most notable is the shift in DEFRA from a regulatory/monitoring approach to explicit volume limitation, though DEFRA certainly has plenty of fine tuning of its own. Indeed, the provisions of these two Acts are, on the whole, far more alike than dissimilar. Both involve detailed regulation of municipals, particularly IDB's. And each imposes a major new limitation on the issuance of these bonds, of a scope not seen since the late 1960's.

In supporting restrictions on tax-exempt obligations, the Administration is following the example of previous presidents and secretaries of the Treasury who have virtually without exception since 1913 sought to limit the use of taxexempt financing by state and local governments. ${ }^{32}$ Tax exemption of municipals, built into the first income tax after passage of the sixteenth amendment ${ }^{33}$ and retained ever since, has long been attacked as providing a subsidy to the rich which erodes the progressivity of the federal income tax. ${ }^{34}$ It provides an implicit subsidy to borrowing state and local governments, but the subsidy is inefficient, since it reduces federal tax revenues by a greater amount than is gained by the issuing governments in interest cost savings. ${ }^{35}$ Moreover, exemption of bonds issued by other issuers may make debt financing relatively more difficult for state and local government. At a time of growing budget deficits, limiting the volume of tax-exempt bonds may seem particularly attractive. As one observer put it, "[c]urtailing the volume of exempt bonds helps close the budget gap without appearing to raise anyone's taxes, since the rate which applies to interest on the bonds that survive remains the same: zero." 36

In the early years of the income tax, several presidents, most notably Franklin Roosevelt, unsuccessfully tried to abolish the municipal bond exemption. ${ }^{37}$ Since 1968 , the attack on the exemption has taken the form of

30. On June 15, 1983, John Chapotin, Assistant Treasury Secretary for Tax Policy, told the House Ways and Means Committee that the Treasury strongly supported "state volume limitations or other comprehensive restrictions applicable to all types of private purpose tax-exempt bonds." See Administration Favors Limits on Use of Tax-Exempt Bonds, 19 TAX NotEs 1103 (1983).

31. See generally H.R. REP. No. 861, 98th Cong., 2d Sess. 1199-1218, reprinted in 1984 U.S. CodE Cong. \& AD. NEwS No. 6B, 751, 1193-1228.

32. See D. OTt \& A. Meltzer, supra note 11, at 1; Derrick, Exemption of Security Interest from Income Taxes in the United States, Pt. 1, App., 19 J. Bus. (1946).

33. Act of October 3, 1913, Ch. 16, \& 11, 38 Stat. 114, 168.

34. See, e.g., D. OTt \& A. MetTzer, supra note 11 , at 10-11; see also sources cited $i d$ at 11 .

35. E.g., D. OTT \& A. MetTzER, supra note 11, at 15, 81, and passim chs. 4-6.

36. Thomas, An Analysis of the New Industrial Development Bond Rules, 24 TAX Notes 691, 691 (1984).

37. See Derrick, supra note 32, at 19. 
limiting its scope rather than attempting outright abolition. ${ }^{38}$ This has been done by denying tax-exempt status to specific categories of bonds where potential or actual abuse has seemed particularly objectionable. Thus in 1968, exemption for most IDB's was eliminated, ${ }^{39}$ and the following year the exemption was eliminated for "arbitrage bonds," issues used to finance the purchase of higher-yielding, "taxable" securities rather than capital construction or some other governmental purpose. ${ }^{40}$ Further modifications were made in $1976^{41}$ and in $1978^{42}$ and $1980.4^{43}$ It is not, however, unreasonable to suggest that the legislation enacted during the first Reagan Administration constitutes the most dramatic change in the tax treatment of municipals since the 1968-1969 enactments.

II

\section{INDUSTRIAL DEVElopMent BondS}

The great bulk of recent legislation relating to tax treatment of state and local obligations has been directed at IDB's, including measures to limit the volume of IDB's issued and a number of provisions changing and specifying in greater detail the eligibility requirements for tax exemption. IDB's in 1982 constituted approximately half of all state and local government borrowing; ${ }^{\mathbf{4 4}}$ to the extent that these new restrictions and regulations significantly reduce the volume of IDB's issued, they have obvious potential for reducing yields on other tax-exempt issues, as well as for increasing federal tax revenues and

38. In the late 1960's and 1970's, considerable enthusiasm was expressed in Congress and elsewhere for some Urbanks-type arrangement by which state and local governments would voluntarily refrain from issuing tax-exempt bonds, in exchange for direct federal subsidies and guarantees to support their (taxable) borrowing. See, e.g., Bagwell, Evans \& Neilson, The Municipal Bond Market: An Analysis and Suggested Reform, 16 HARv. J. ON LEg. 211 (1979); Galper \& Petersen, An Analysis of Subsidy Plans to Support State and Local Borrowing, 24 NAT'L TAX J. 205 (1971); Galper \& Peterson, The Equity Effects of a Taxable Municipal Bond Subsidy, 26 NAT'L TAX J. 611 (1973).

39. Revenue and Expenditure Control Act of 1968, Pub. L. No. 90-364, § 107 (a), 82 Stat. 251, 266, amended in Renegotiation Amendments Act of 1968, Pub. L. No. 90-634, $\$ 401$ (a), 82 Stat. 1345, 1349 (codified as amended at I.R.C. $\$ 103$ (b) (Lawyers Co-op. 1984)).

40. Tax Reform Act of 1969, Pub. L. No. 91-172, § 601, 83 Stat. 487, 656 (codified as amended at I.R.C. \& 103(c) (Lawyers Co-op. 1984)).

41. Tax Reform Act of 1976, Pub. L. No. 94-455, $\$ \$ 1901,1906,2105,2137,90$ Stat. 1520, 1764-66, 1834, 1902, 1931 (codified at I.R.C. \& 103 passim (Lawyers Co-op. 1984)).

42. Revenue Act of 1978, Pub. L. No. 96-600, $\$ \$ 331-334,92$ Stat. 2763, 2839-4l (codified at I.R.C. $\$ 103(\mathrm{~b})(4),(6)(\mathrm{D}),(7)$ (Lawyers Co-op. 1984)); id. $\$ 703(\mathrm{q})(1), 92$ Stat. at 2844, amended by Technical Corrections Act of 1979, Pub. L. No. 96-222, \&107(a)(3)(C), 94 Stat. 194, 223 (1980) (codified at I.R.C. \& 103(c)(5) (Lawyers Co-op. 1984)).

43. Crude Oil Windfall Profit Tax Act of 1980, Pub. L. No. 96-223, \& \& 241, 242, 244, 94 Stat. 229, 281, 283, 286 (codified at I.R.C. $\$ 103($ b)(4)(E), (4)(H), (8) (Lawyers Co-op. 1984)); Mortgage Subsidy Bond Tax Act of 1980, Pub. L. No. 96-499, \& 1103, 94 Stat. 2660, 2669 (codified as amended at I.R.C. \& 103(b)(4)(A), (12), (13) (Lawyers Co-op. 1984)). In addition, new categories of exempt purpose IDB's were created by the Revenue Act of 1971, Pub. L. No. 92-178, \& 315, 85 Stat. 497, 529 (water facilities) (codified at I.R.C. \& 103(b)(4)(G) (Lawyers Co-op. 1984)); Revenue Adjustment Act of 1975, Pub. L. No. 94-164, \& 7(a), 89 Stat. 970, 976, and Social Security Act, Pub. L. No. 94-182, \& 301, 89 Stat. 1051, 1056 (1975) (irrigation facilities) (codified at I.R.C. \& 103(d) (Lawyers Co-op. 1984)).

44. According to Treasury estimates, the volume of private activity bonds in 1982 was $\$ 44.0$ billion, $51.7 \%$ of total state-local borrowings (up from $\$ 6.2$ billion (21\% of total) in 1976). H.R. Rep. No. 432, 98th Cong., 1 st Sess. 375 (1983). 
progressivity. ${ }^{45}$ Moreover, claims of abuse in IDB issuance, and calls for correction, have been expressed with mounting volume in both academic and political forums, and the legislation seems designed to respond to this criticism. ${ }^{46}$

\section{A. Background}

IDB's are a kind of hybrid between private (corporate) bonds and revenue bonds. ${ }^{47}$ Issued by an agency or authority of state or local government, they are used to finance the authority's acquisition of assets which are then sold or leased to a private user who assumes responsibility for the bond payments. ${ }^{48}$ By Code definition, an IDB is an obligation whose proceeds are used primarily in the trade or business of a nonexempt (taxable) person, ${ }^{49}$ when payment of the bond's principal or interest is primarily (1) secured by an interest in property used in trade or business of the user, or (2) secured by or derived from payments placed through banks, and their design is generally determined by interaction of the bank with the principal user. ${ }^{50}$ In many cases, the government agency which actually issues the bonds plays a passive

45. Tax exemption of municipals was built into the first income tax after passage of the sixteenth amendment, see Act of October 3,1913, Ch. 16, \& II, 38 Stat. 114, 168, and has been retained ever since. It has long been attacked as providing a subsidy to the rich which erodes the progressivity of the federal income tax. See, for example, D. OTt \& A. MeLTzER, supra note 11, at 10-11, and sources cited therein at 11. Exemption provides an implicit subsidy to state and local governments, but the subsidy is inefficient, since it reduces federal tax revenues by a greater amount than is gained by the issuing governments in interest cost savings. E.g., id. at 15, 81, and passim chs. 4-6. The exemption is also considered inequitable in that taxpayers in the highest tax brackets who invest in municipals receive favorable tax treatment relative to those similarly situated who do not so invest, see, e.g., J. Maxwell \& J. Aronson, Financing State and Local Governments 202-04 (1977). See generally Buchanan, Federalism and Fiscal Equity, 40 AM. Econ. REv. 583 (1950), and also in that the benefits of tax exemption as a subsidy to the states go disproportionately to those states where per capita income is highest, see C. Kent, The Subsidy to State and Local Governments Implicit in the Exemption of Municipal Bond Interest From Federal Tax (unpublished dissertation, Lehigh University, 1975), ciled in J. MAXWELl \& J. Aronson, supra, at $206 \mathrm{n} .22$. As a form of transfer from the federal to state and local governments, however, the exemption may be useful in helping to correct a "vertical imbalance" which has occurred as the demand for those services traditionally supplied by states has grown at a faster rate than their revenue sources, while the reverse has been true of the federal government. See W. Heller, New Dimensions of Polrtical Economy ch. 3 (1967).

46. See, e.g., Dobbs \& Joslin, Bankruptcy Preference Concerns in Industrial Development Bond Financing, 84 W. VA. L. REv. 573, 577 n.9 (1982); Note, Industrial Development Bonds: The Growing Abuse, 39 WASH. \& LEE L. REV. 223 (1982).

47. Congressional Budget Office, Small Issue Industrial Revenue Bonds 52 (1981) [hereinafter cited as SMALL IssuE]. No distinction is made here between Industrial Development Bonds (IDB's) and Industrial Revenue Bonds (IRB's). The terms are commonly interchangeable. $C f$. id. at $1 \mathrm{n} .1$ (finds a technical distinction between IDB's, as bonds backed by full faith and credit of the issuing authority, and IRB's, "backed solely by the revenues from the projects or the facility itself.").

48. See, e.g., id. at 1; Dobbs \& Joslin, supra note 46, at 579-84.

49. I.R.C. $\$ 103$ (b)(2), (3) (Lawyers Co-op. 1984); see Treas. Reg. \& 1.103-7 (1982); Roberts, Industrial Development Bond Financing: Section 103(b) Examined, 32 U. FLA. L. REv. 1 (1979). Exempt persons are "governmental"; but since the term "governmental" refers to state government and its subdivisions, the federal government may be a "nonexempt person" within the meaning of I.R.C. $\$ 103$ (b). See Fairfax County Econ. Dev. Auth. v. Commissioner, 77 T.C. 546 (1981), affd, 679 F.2d 261 (D.C. Cir. 1982). But see infra text accompanying notes 258-60.

50. SMaLl Issue, supra note 47 , at xiii, $24-25$. 
role; in others, however, there is a degree of agency supervision and control. ${ }^{51}$

IDB's were first issued in Mississippi in 1936.52 For a number of years thereafter, only a very limited number of these bonds were issued, at least in part because of states' constitutional or statutory prohibitions against "lending" the credit of the states to private borrowers ("credit clauses") or for other than a "public purpose." 53 However, these restrictions, some of which date back to railroad and canal bond defaults of the nineteenth century, were gradually relaxed in a number of states. ${ }^{54}$

Judicial interpretation played a key role in this relaxation. In Kentucky, for example, a 1950 decision held that IDB's were not truly debt of the issuing government and therefore a public purpose requirement did not apply. ${ }^{55}$ Florida courts interpreted a constitutional requirement that "the credit of the state shall not be ... loaned" 56 as requiring only a "paramount public purpose." The result was that racetracks and other facilities designed to attract tourists were found in 1952 to conform to a public purpose of assisting the state in economic development. ${ }^{57}$ This liberal interpretation of the public purpose requirement was followed in many, though not all, states, ${ }^{58}$ providing

51. See id. at 19-20. North Carolina is one state where "rigorous criteria" are applied. Id. at 20.

52. The bonds were authorized by the Mississippi Industrial Act, 1936 Miss. Laws, 1st Extraord. Sess. ch. 1, repealed by Act of April 26, 1940, § 10, 1940 Miss. Laws ch. 147, and were used to construct hosiery mills in Durant, see SMALL IsSUE, supra note 47, at 7, and in Winona, see Albritton v. City of Winona, 181 Miss. 75, 92-95, 178 So. 799, 802-03, appeal dismissed, 303 U.S. 627 (1938). "The care of the poor, the relief of unemployment, and the promotion of agriculture and industry are undoubtedly proper governmental purposes." Albritton, 181 Miss. at 97-98, 178 So. at 804 . See generally Abbey, Municipal Industrial Development Bonds, 19 VAND. L. REV. 25, $27-28$ (1965).

53. By 1977, the constitutions of 44 states contained some such prohibition, which extended to guarantees of municipal corporate indebtedness. Comment, State Constitutional Prohibitions Against the Lending of State Credit to Municipal Corporations, 26 AM. U.L. REv. 657, 668-69 (1977). "Underlying the prohibitions originally was the clear assumption that subsidizing private, profit-making corporations was an improper governmental activity." Id. at 669 (citing H. SECRIST, An Economic ANALYSIS OF the Constitutional Restrictions upon Public Indebtedness in the United States 69 (1914)).

The first enunciation of the public purpose doctrine is commonly attributed to Sharpless v. Mayor of Philadelphia, $21 \mathrm{~Pa}$. 147, 169 (1853) (the state's fiscal resources are to be used for public purposes only). The Supreme Court has tacitly approved the doctrine in affirming decisions based on it. See, e.g., Citizens' Sav. \& Loan Ass'n v. City of Topeka, 87 U.S. (20 Wall.) 655 (1874). For background discussion of the public purpose doctrine, see Abbey, supra note 52; Comment, supra at 669-74; sources cited id. at 669 n.57.

54. See SMall Issue, supra note 47, at 2; Note, State and Local Industrial Location Incentives-A WellStocked Candy Store, 5 J. CoRP. L. 517, 538-45 (1980); sources cited id. at 540 n.187.

55. See Faulconer v. City of Danville, 313 Ky. 468, 232 S.W.2d 80 (1950); see also Woods v. Homes \& Structures, 489 F. Supp. 1270 (D. Kan. 1980) (tenth amendment no bar to issuer liability because IDB's do not rise to the level of a traditional government function). Ironically, Alabama, which, along with Mississippi and Kentucky, was one of the only states to permit IDB's in 1950, recently rejected this view of the public purpose test. See Recent Decisions, Out in the Cold: McDonald's Corp. v. DeVenney Excludes Retail Enterprises from Alabama Industrial Development Statutes, 34 Ala. L. Rev. 297, 297-304 (1983).

56. Fla. Const. art. IX, \& 10 (1885).

57. See Case Comment: Industrial Development Bonds: The Demise of the Public Purpose Doctrine, 35 U. FuA. L. Rev. 541, 541-42 (1983). Subsequent decisions, and a 1968 constitutional revision, opened the way gradually for industrial and commercial projects generally. See id. at 542-54.

58. See, e.g., R.E. Short Co. v. City of Minneapolis, 269 N.W.2d 331, 397 (Minn. 1978) (" "public purpose' should be broadly construed to comport with the changing conditions of modern life"). See 
a legal sanction for state and local governments to use IDB availability as a vehicle for competing with one another for plant locations and tourist trade. ${ }^{59}$

In the earliest years of IDB issuance, those few states authorizing them were relatively poor.60 Possibly because of their limited use and their apparently progressive effect in relieving hard-core unemployment in particularly depressed locations, the IRS in a 1954 Revenue Ruling confirmed what had previously been an ad hoc, informal practice of accepting these bonds as "state or local obligations" for purposes of tax exemption, thereby excluding IDB interest from gross income exempt under the provisions of Code section 103.61 After this confirmation was reiterated in another Revenue Ruling in 1957, ${ }^{62}$ the volume of IDB's increased dramatically. Three states authorized IDB's in 1950; in 1960 the number was seventeen, and by 1968 at least forty states authorized IDB's and the volume outstanding had risen from $\$ 100$ million in 1960 to $\$ 1.8$ billion in $1968 .{ }^{63}$

Many of these IDB issues were virtually indistinguishable from strictly private borrowing in the uses to which they were put. During the period 1962 to 1967 , for example, IDB's were used to finance nearly all the nation's new tire plant construction. ${ }^{64}$ Even when it was applied, the public purpose doctrine, liberally interpreted, was a generally ineffective deterrent to such borrowing. In March, 1968, the IRS reversed its earlier position and ruled that IDB's were not "obligations of a State or any political subdivision" within the meaning of Code section 103 and that IDB interest was, accordingly, taxable. ${ }^{65}$ Congress confirmed this ruling in the Revenue and Expenditure Control Act of 1968.66

generally Small Issue, supra note 47, at 19-20; Bruff, Judicial Review in Local Government Law: A Reappraisal, 60 MinN. L. Rev. 669, 687 (1976).

59. The availability of IDB financing may be of only marginal importance in attracting new business to a particular location. See, e.g., SMALL Issue, supra note 47, at 48-50; Lamberson, Industrial Development Bonds Can Tip the Balance in Site Selection, 146 InDUs. Dev. 16 (1977); Note, supra note 54, at 545-47. But see Fening \& Russo, The Impact of Industrial Revenue Bonds on Job Generation and Economic Development, 8 Current MUN. Probs. 143, 143 (1981) (IRB's probably important to investment decision and a comparatively efficient subsidy for local job creation).

60. In 1950, the three states which authorized IDB's, Alabama, Kentucky, and Mississippi, ranked 46th, 44th, and 48th respectively (out of 48 states) in per capita income. See SMall Issue, supra note 47, at 7; U.S. Dept. of Commerce, Historical. Statistics of the United States 243-45 (1975) (Series F297-348, Personal Income, by States, 1929-1970).

61. Rev. Rul. 54-106, 1954-1 C.B. 28.

62. Rev. Rul. 57-187, 1957-1 C.B. 65.

63. Small Issue, supra note 47, at 7-9; see Mitchell v. North Carolina Indus. Dev. Fin. Auth., 273 N.C. 137,159 S.E.2d 745 (1968).

64. Small Issue, supra note 47 , at 9.

65. Proposed Treas. Reg. $\$ 1.103-7$ (1968), withdrawn, 34 Fed. Reg. 508 (1969). The IRS proposal was "based on the theory that industrial development bonds . . . were not 'obligations of a State or any political subdivision' within the meaning of section 103 since the primary obligor was not a State or political subdivision." Conf. REP. No. 1533, 90th Cong., 2d Sess. 32, reprinted in 1968 U.S. Code Cong. \& Ad. News 2373, 2379.

66. Revenue and Expenditure Control Act of 1968, Pub. L. No. 90-364, \& 107, 82 Stat. 251, 266 (codified at I.R.C. \& 103(b) (Lawyers Co-op. 1984)). 
Since 1968, the general rule has been that IDB's are fully taxable obligations. ${ }^{67}$ The 1968 Act contained two exceptions, however: IDB's used to finance certain specific kinds of "exempt facilities",68 and IDB's which qualify as "small issues", ${ }^{69}$ continue to be treated as state or local government obligations for the purposes of tax exemption. These two exceptions have been preserved since $1968,{ }^{70}$ with only a few statutory modifications prior to 1982.

\section{B. Small Issues and Exempt Facilities}

Tax exemption for exempt facility bonds is justified primarily by the quasipublic purpose for which they are used. ${ }^{71}$ Bonds used to finance purchase or construction of industrial parks; family residences; sports, convention, and trade show facilities; pollution control and waste disposal facilities; local utilities; and a variety of transportation facilities including airports, docks, and facilities for mass commuting and parking were originally exempted in the 1968 Act. ${ }^{72}$ Subsequent enactments added government-owned hydroelectric generating facilities ${ }^{73}$ and facilities furnishing water to the general public, subject to state or federal rate setting or control. ${ }^{74}$ The Mortgage Subsidy Bond Tax Act of 1980 changed the original provision for IDB financing of private housing: it established a new category of bonds, exempt under new Code section 103A, used to finance "single family residences which can reasonably be expected to become the principal residences of the mortgagors," and removed tax exemption generally from other kinds of mortgage bonds. ${ }^{75}$ However, obligations used to finance multifamily residences where a specified percentage of the units were to be occupied by persons with low or moderate income remained exempt under section $103 .{ }^{76}$

By contrast to exempt facility bonds, small issues were originally exempted not because of the public purpose served by the financed facilities but because of their role in providing economic assistance to certain regions and types of borrowers felt to be particularly in need of help. Specifically, the small issue bond was designed principally to assist small businesses in financing capital construction. ${ }^{77}$ Small, new businesses were considered to be particularly

67. I.R.C. \& 103(b)(1) (Lawyers Co-op. 1984). The terms "taxable" and "tax-exempt" are not quite correct, in that the "exemption" is provided as an exclusion of bond interest from (taxable) gross income. Id. $\$ 103(\mathrm{a})$. They are, however, customary and convenient terms and are thus employed here.

68. Id. \& 103(b)(4), (5) (Lawyers Co-op. 1984).

69. Id. \& $103(\mathrm{~b})(6)$.

70. TEFRA scheduled the end of the small issue exemption for bonds issued after 1986, now extended until 1986 for manufacturing facility bonds. See infra notes 90-121 and accompanying text.

71. See Treas. Reg. \& 1.103-8(a)(2) (1972); Roberts, supra note 49, at 20-21.

72. I.R.C. $8103(\mathrm{~b})(4)(\mathrm{A})-(\mathrm{F})$, (5) (Lawyers Co-op. 1984).

73. Id. \& $103(\mathrm{~b})(4)(\mathrm{H})$.

74. Id. \& $103(\mathrm{~b})(4)(\mathrm{G})$.

75. Id. $8 \& 103(\mathrm{~b})(4)(\mathrm{A}),(12),(13), 103 \mathrm{~A}$.

76. Id. $8103(\mathrm{~b})(4)(\mathrm{A})$.

77. See 114 CoNG. REc. 30,603 (1968) (statement of Rep. Mills); Small IssuE, supra note 47, at 10. See generally Note, The Limited Tax-Exempt Status of Interest on Industrial Development Bonds under 
vulnerable to credit contractions such as the credit "crunch" of the late 1960's, since their relations with banks were not so well established and they typically had less collateral and greater operating risk than larger, more established firms. ${ }^{78}$ Another purpose may have been to provide aid for poor, rural areas of the country where the need for job creation and industrialization was particularly acute. ${ }^{79}$ In light of recent claims of abuse of the small issue, it seems important to note that both in the original Act and in its legislative history there is no mention or requirement that facilities financed by small issues serve any identifiable public purpose. ${ }^{80}$

The small issue exception provides tax exemption for IDB issues whose "aggregate authorized face amount" is $\$ 1$ million or less, as long as "substantially all" of the proceeds are used to acquire, construct, rebuild, or improve land or depreciable property. ${ }^{81}$ The aggregate authorized face amount includes outstanding prior issues used to finance facilities located in the same city or county whose "principal user" 82 is the same person as the principal user of the new issue ${ }^{83}$ or is a "related person." 84 As an alternative to this $\$ 1$ million safe harbor, the Code provides an option for the issuer to substitute $\$ 10$ million for the $\$ 1$ million "clean" limit. If this option is selected, aggregate authorized face amount is recalculated to include total capital expenditures with respect to the financed facilities, paid or incurred during the six-year period beginning three years before the date of such issue, "as if the aggregate amount of such capital expenditures constituted the face amount of a prior outstanding issue." 85 Thus, while a "small" facility costing

Subsection 103(c) of the Internal Revenue Code, 85 HARv. L. REv. 1649 (1972); Note, Small Issue Industrial Development Bonds: The Growing Abuse, 39 W. \& LEE L. REv. 223 (1982) [hereinafter cited as Small Issue $I D B$ 's].

78. See 114 Cong. Rec. 30,603 (1968) (statement of Rep. Mills).

79. See, e.g., Proposed Legislation Relating to Amendment of Internal Revenue Code: Hearings on H.R. 15414 Before the Senate Comm. on Finance, 90th Cong., 2d Sess. 82 (1968) (statement of Sen. Ribicoff); see generally Small Issue IDB's, supra note 77, at 225-31.

80. See, e.g., Roberts, supra note 49, at 20-21. Compare Treas. Reg. $\$ 1.103-10$ (b)(1)(ii) (1972) ("Any obligation which is an industrial development bond . . . and which satisfies the $\$ 1$ million small issue exemption requirements is an exempt small issue.”) with Treas. Reg. \$1.103-8(a)(2) (1972) ("To qualify . . . as an exempt facility, a facility must serve or be available on a regular basis for general public use.").

81. I.R.C. $\$ 103($ b)(6)(A) (Lawyers Co-op. 1984). "Substantially all" is defined at Treas. Reg. $\$ \$ 1.103-8(a)(1)(i), 1.103-10$ (b)(1)(ii) (1972) to mean 90\% or more. See Rev. Proc. 79-5, 1979-1 C.B. 485; Doyle, Recent Rulings on Tax-Exempt Financing Highlight Restrictive IRS Positions, 58 TAXES 175, 180, $183(1980)$.

82. "Principal user" is not defined in the Code or regulations for this subsection of $\$ 103$. However, Letter Ruling 7817108 (Sept. 1976) has interpreted the term to refer to any person using more than $10 \%$ of a facility. See Doyle, supra note 81 , at 181 . This interpretation suggests that there may be more than one "principal user" of a facility. Wade, however, suggests in the alternative that "the" principal user will be that one person using more than $10 \%$ who uses more of the facility than any other user. See Wade, Industrial Development Bonds-The Capital Expenditure Rule for $\$ 10,000,000$ Small Issues, 34 Bus. LAw. 1771, 1775-76 (1979).

83. I.R.C. \& 103(b)(6)(B) (Lawyers Co-op. 1984).

84. Id. \& 103(b)(6)(B), (C). See generally Wade, supra note 82, at 1773 (the "related person rule"); id. at 1774-75 (the "location rule").

85. I.R.C. \& 103(b)(6)(D) (Lawyers Co-op. 1984). The issuer must file an appropriate election prior to issuance, Treas. Reg. \& 1.103-10(b)(2)(vi) (1972); see Continental Bank v. United States, 517 F. Supp. 918 (E.D. Pa. 1981), and the election, once made, is irrevocable, Rev. Rul. 76-375, 1976-2 
$\$ 10$ million or less can be financed entirely with a tax-exempt small issue, only $\$ 1$ million of clean limit bonds may be used in financing larger projects. This capital expenditure limit reflects the original purpose of the small issue exemption to assist small business, but its effect in curtailing use of the exemption by large firms has probably been, at best, minimal.

\section{III}

\section{Restricting and Eliminating the Small Issue Exemption}

Perhaps the most important TEFRA provisions affecting Code section 103 are those which single out the small issue IDB for immediate curtailment and eventual extinction. The Act immediately eliminated exemption for small issues used for specified purposes ${ }^{86}$ and scheduled the end of all small issue exemption for bonds issued after 1986. These measures, apparently enacted at least partly in response to some known instances of past misuse, were supplemented by a reporting requirement designed to uncover further cases of abuse. ${ }^{87}$ In DEFRA, despite a partially successful Senate attempt to extend the sunset beyond $1986,{ }^{88}$ these provisions were generally left in place and, indeed, supplemented with further interim limitations. Most notably, a pertaxpayer small issue volume cap was imposed in DEFRA on bonds issued after 1983 , seemingly in response to the same misuse which inspired the TEFRA sunset legislation. ${ }^{89}$

\section{A. Sunset Legislation}

The volume of small issues has increased dramatically in recent years. From a minimal level in the early 1970's, small issue borrowing by 1982 topped $\$ 10$ billion-over $10 \%$ of outstanding state and local government debt, more than half of which was comprised of IDB's and other private activity bonds. ${ }^{90}$ During the period 1976 to 1981 , small issue borrowing grew at an average rate of $50 \%$ per year. ${ }^{91}$

C.B. 27. Exceptions to the $\$ 10$ million limit are provided for expenditures necessitated by casualty losses or subsequent acts of government or (up to $\$ 1$ million) by force majeure. See I.R.C. $\$ 103(b)(6)$ (F) (Lawyers Co-op. 1984). For facilities for which an Urban Development Action Grant (UDAG) has been made, $\$ 10$ million of capital expenditure is excluded from the computation. Id. $\$$ 103(b)(6)(I). See generally Tax Clinic: IDB User Filing Requirements, 13 TAX AdvisER 666, 673-78 (1982); Podolin \& O'Leary, Capital Expenditure Problems Under the Ten Million Dollar Exemption for Industrial Development Bonds, 33 TAx LAw. 153 (1979).

86. See infra notes $125-34$ and accompanying text.

87. See infra notes 107-13 and accompanying text.

88. See infra notes 117-21 and accompanying text.

89. See infra notes $\mathbf{1 3 5 - 4 7}$ and accompanying text.

90. See H.R. ReP. No. 432, 98th Cong., 1st Sess. 375, reprinted in 1983 U.S. Code Cong. \& AD. News 781, 930; S. REP. No. 494, 97th Cong., 2d Sess. 168, reprinted in 1982 U.S. Code Conc. \& AD. News 781, 930.

91. S. Rep. No. 494, 97th Cong., 2d Sess. 168, reprinted in 1982 U.S. Code Cong. \& Ad. News $781,930$. 
Accompanying this growing volume of small issue debt was increasingly vociferous criticism of the small issue exemption. Articles, ${ }^{92}$ newspaper accounts, ${ }^{93}$ and congressional studies ${ }^{94}$ have contained a variety of "horror stories" suggestive of widespread abuse. "Abuse" in this context includes the absence of a clear public purpose, and it seems useful in this context to recall that neither the legislation authorizing the small issue exception nor related Treasury regulations impose any public purpose requirement on these issues. ${ }^{95}$ However, the original purposes of aiding small business and fostering development of economically distressed areas were apparently often not being served either.

One problem is that large corporations also utilized small issue financing. Many of the $\$ 1$ million issues were apparently used in conjunction with other project financing, as is suggested by the fact that a very large number of these clean limit bonds were issued for precisely $\$ 1$ million face value. ${ }^{96}$ Moreover, large corporations whose operations consist of "a large number of relatively low-cost and geographically dispersed facilities" could use IDB's to finance these facilities, simply by spreading them out into different cities and counties in such a way as to keep total facility costs in each jurisdiction under $\$ 10$ million. ${ }^{97}$ Thus, for example, K-Mart financed nearly 100 stores between 1975 and 1980 with $\$ 220.5$ million of tax-exempt small issues, while McDonald's used small issues to open thirty-two new restaurants in 1979 in Pennsylvania and Ohio alone. ${ }^{98}$

These relatively infamous issues were public placements; most small issues are privately financed through banks and were not, prior to TEFRA, subject to any reporting requirements which would reveal the prevalence of this kind of small issue. ${ }^{99}$ Thus, it is simply not known to what extent small issue IDB's were being used by large corporations rather than by the small firms they were intended to assist, nor is it clear to what extent the tax-exempts contributed to regional development of economically distressed areas or to net job creation in the economy as a whole. ${ }^{100}$

What was evident, however, is that by 1982 the volume of small issues had become substantial. At the same time, they did not appear to be serving any real public purpose. It was felt by many critics that the volume of small issues had reached a level which could no longer be ignored: the mounting amount

92. See, e.g., Craig, Impact of Federal Policies on Municipal Bond Financing, 34 Nat'L TAX J. 389, 391 (1981)

93. E.g., Hertzberg, On the Bondwagon: Use of Tax-Exempt Financing for Stores and Other Business Soars, Stirring Critics, WALl ST. J., Oct. 8, 1980, at 56, col. 1.

94. See, e.g., Small Issue, supra note 47 , at 23-24, 31.

95. See supra notes 77-80 and accompanying text.

96. See, e.g., Small Issue, supra note 47 , at 23-24.

97. Id. at 23.

98. Id.

99. Id. at xiii.

100. See supra note 59 . "[S]mall issues primarily reallocate capital without generating much new investment." SMALL Issue, supra note 47 , at 66 . 
of small issue debt was impairing the ability of state and local governments to use debt financing for other, more obviously social, purposes. ${ }^{101}$

It was in response to such criticism, at least in part, that the Senate Finance Committee in 1982 added to TEFRA a provision by which the small issue exemption of Code section 103(b)(6) would expire as to obligations (including refundings) issued after $1986 .{ }^{102}$ The accompanying Senate Report cites, as reasons for this provision, concern that small issue IDB's were being used (1) by "large companies that are able to raise funds readily in capital markets without a federal subsidy," 103 and (2) "to finance a variety of types of facilities, from private recreational facilities to fast food restaurants, that generally may be less deserving of a federal credit subsidy than other types of facilities; ${ }^{104}$ moreover, (3) no "substantial targeting" assured the use of small issue IDB's in impoverished areas where economic stimulation would be particularly appropriate. ${ }^{105}$ Additional concern was expressed for the mounting volume of total tax-exempt debt, with concomitant reduction in federal revenues, distortion of capital markets, and increased cost of financing traditional state and local governmental functions such as schools, roads, and prisons. ${ }^{106}$

1. Reporting Requirement. Despite its apparent conviction that the small issue exemption is undesirable, the committee in its explanation of the provision linked it to a reporting requirement and suggested that further congressional consideration of the small issue IDB would be appropriate after greater information becomes available. ${ }^{107}$ The TEFRA reporting requirement, which also originated in the Senate, applies to all private activity tax-exempt bonds, not merely small issues. ${ }^{108}$ Issuers of these bonds are required to report quarterly to the Treasury basic information about each new borrowing, identifying the issuer, source of authorization, and principal user, as well as describing the bond issue itself and the property to be financed by its proceeds. ${ }^{109}$

While this level of reporting seems minimal and is not expected to have any discernible direct affect on the use of IDB's, ${ }^{110}$ the provision is noteworthy in that it establishes the first widespread reporting requirements

101. In 1982 the Board of Directors of the Public Securities Association (the national trade organization of banks and broker/dealers that underwrite, trade, and sell municipal bonds) unanimously approved a resolution that "small issue industrial revenue bonds have had an adverse effect on the municipal securities market" and urged state and local governments to curb small issue borrowings. 14 TAX NOTES 400 (1982).

102. I.R.C. \& $103(\mathrm{~b})(6)(\mathrm{N})$ (Lawyers Co-op. 1984).

103. S. Rep. No. 494, 97th Cong., 2d Sess. 169, reprinted in 1982 U.S. Code Cong. \& Ad. News 781,931 .

104. Id.

105. See id.

106. Id. at 167-69, reprinted in 1982 U.S. CoDE Cong. \& AD. News at 929-31.

107. Id. at 169 , reprinted in 1982 U.S. CODE CoNG. \& AD. NEws at 931.

108. I.R.C. \& 103(l) (Lawyers Co-op. 1984).

109. Id.

110. See, e.g., Winston, Industrial Development Bonds Afler TEFRA, 61 TAXEs 20, 23 (1983). 
for state and local government debt instruments. ${ }^{111}$ The Securities and Exchange Commission requires registration of publicly placed IDB issues in excess of $\$ 300,000$, a requirement which has been cited in explanation of the fact that almost all IDB's are privately placed. ${ }^{112}$ No systematic reporting was available prior to TEFRA, however, and the resulting "absence of comprehensive and reliable information" about IDB's in general and the small issue IDB in particular was cited by the Senate Committee as the reason for imposing this requirement in TEFRA. ${ }^{113}$

2. The Sunset Provision after TEFRA. In linking the small issue sunset to the new reporting requirements, the Senate Committee Report seems to indicate that the sunset provision was to be regarded as tentative, with a distinct possibility left open that Congress would subsequently restore some form of the small issue exemption. ${ }^{114}$ However, this was not the prevalent view of the sunset provision after its enactment. Rather, analysts ${ }^{115}$ and Congress ${ }^{116}$ alike seem to have treated the scheduled demise of the small issue exemption as a fait accompli.

The sunset provision, however, was not unopposed. In the past decade a disproportionate volume of small issue IDB's have been issued in the northern and northeastern parts of the country, ${ }^{117}$ and many representatives of these areas, among others, expressed opposition to the sunset. ${ }^{118}$ Possibly because of this opposition, the Senate-which had originated the legislationsought in DEFRA to extend its deadline from December 31, 1986, to

111. General obligations and revenue bonds need not be reported under the TEFRA reporting requirements. See I.R.C. $\$ 103(l)$ (Lawyers Co-op. 1984). In 1978, an unsuccessful attempt was made to require IDB registration with the SEC. See S. 3323, 95th Cong., 2d Sess. (1978).

112. 17 C.F.R. $\$ 230.131$ (1984); id. \& 240.365; see Small Issue, supra note 47, at 12; Kreiser \& Rini, When to Finance Pollution Control Facilities with Tax-Exempt Industrial Development Bonds and Elect FiveYear Amortization, 58 TAXEs 283, 288 (1980); Steinberg, Municipal Issuer Liability Under the Federal Securities Laws, 6 J. CORP. L. 277 (1981).

113. See S. Rep. No. 494, 97th Cong., 2d Sess. 169-70, reprinted in 1982 U.S. Code Cong. \& AD. NEWS 781, 931-32.

114. See id.

115. See generally Petersen, Doty, Forbes \& Bourque, Searching for Standards: Disclosure in the Municipal Securities Market, 1976 Duxe L.J. 1177; Comment, Federal Regulation of Municipal Securities: A Constitutional and Statutory Analysis, 1976 DUKE L.J. 1261.

116. See, e.g., H.R. REP. No. 432, Pt. 1, 98th Cong., 2d Sess. 369 ("TEFRA provided that the small issue exemption will not apply to obligations after December $31,1986 . ")$.

117. In 1979, $45 \%$ of small issue IDB's came from Pennsylvnia (25\% of total issues), Minnesota, New Jersey, and Ohio, four states that together had only $15 \%$ of the nation's population. SMALI Issue, supra note 47, at 27; see U.S. Dep't of Commerce, Statistical Abstract of the UnIted States, 1985, at 11 (Table 11) (1984). Almost 39\% came from the northeast, $28 \%$ from the "north central" United States, and only 3.6\% from the west. Smatl Issue, supra note 47, at 27. Kraft predicts that elimination of IDB's will hurt "older, northeastern communities with eroding tax bases" and argues that this result would be "extremely unfair": "IDBs were originally used in the southern states and have played a major role in the growth of the Sunbelt. Now that the northeastern states have begun to utilize IDBs to upgrade their industrial and commercial base, there is a call for their elimination." Kraft, supra note 13 , at 378 .

118. See, e.g., 20 TAX Notes 172 (1983) (letter from 20 Senators opposing further restrictions on IDB's). 
December 31, 1990.119 This time it was the House which fought to preserve the earlier sunset date. ${ }^{120}$ It was largely successful in this endeavor. DEFRA section 630 , while providing an extension for bonds financing manufacturing facilities through the end of 1988 , otherwise reiterates the December 31 , 1986 , sunset date for all other small issues. ${ }^{121}$

\section{B. Eliminated Categories}

While TEFRA's sunset legislation slated the eventual elimination of the small issue exemption, the exemption was scheduled to remain in force until the end of 1986. In the meantime, TEFRA eliminated immediately the exemption for two specific kinds of small issues: "clean issues" accompanying exempt-purpose IDB's, ${ }^{122}$ and small issues whose proceeds were intended to finance certain specified activities. ${ }^{123}$ The former measure was designed to correct a known abuse: the prevalent practice of using a clean issue ( $\$ 1$ million) bond to cover nonexempt costs related to an exempt-purpose facility which was financed with tax-exempt bonds. ${ }^{124}$ The detailed nature of the latter measure suggests that it, too, was designed to correct known abuses.

TEFRA section $214(\mathrm{e})^{125}$ provides that bonds issued after 1982 are ineligible for small issue exemption if:

(i) more than 25 percent of the proceeds of the issue are used to provide a facility the primary purpose of which is one of the following: retail food and beverage services, automobile sales or service, or the provision of recreation or entertainment; or

(ii) any portion of the proceeds of the issue is to be used to provide the following: any private or commercial golf course, country club, massage parlor, tennis club, skating facility (including roller skating, skateboard, and ice skating), racquet sports facility (including any handball or raquetball court), hot tub facility, suntan facility, or racetrack.

This provision is noteworthy for several reasons. First, the imposition of such detailed specifications suggests that they reflect known abuses ${ }^{126}$ and that Congress is unwilling to leave to Treasury interpretation detailed implementation of its wishes. Second, the legislation represents a break with past policy of leaving the small issue exemption "grant" almost totally open-

119. See H.R. Conf. ReP. No. 861, 98th Cong., 2d Sess. 1209-10, reprinted in 1984 U.S. Code Cong. \& AD. News 1445, 1897-98.

120. Id.; see 130 Cong. Rec. S8373 (daily ed. June 27, 1984) (statement of Sen. Dole).

121. I.R.C. \& 103(b)(6)(N) (Lawyers Co-op. Supp. 1985).

122. Id. \& 103(b)(6)(M) (Lawyers Co-op. 1984).

123. See infra notes $126-34$ and accompanying text.

124. See S. Rep. No. 494, 97th Cong., 2d Sess. 173, reprinted in 1982 U.S. Code Cong. \& Ad. News $781,935$.

125. I.R.C. \& $103(\mathrm{~b})(6)(\mathrm{O})$ (Lawyers Co-op. 1984).

126. In light of the wide publicity given the MCDonald's and K-Mart IDB's, see supra note 98 and accompanying text, it is interesting to note that this section left tax-exempt financing still available to K-Mart and similar stores, while the provision which includes retail food and beverage service in the list of prohibited purposes (in excess of $25 \%$ of proceeds) was not included in the original (Senate) version but was added in the conference committee. See H.R. REP. No. 760, 97th Cong., 2d Sess. 522, reprinted in 1982 U.S. CODE ConG. \& AD. News 781, 1297-98. The DEFRA small issue volume cap, however, seems to have corrected this apparent oversight. See infra notes 135-47 and accompanying text. 
ended, to be used for virtually any kind of private capital construction.127 Third, and possibly most importantly this provision implies a public purpose requirement for the small issue exemption, at least to the extent that exemption is denied to particular categories of small issues which appear not to meet such a requirement. Moreover, this public purpose test is being interpreted and applied at a federal, rather than a state or local, level of determination. ${ }^{128}$

Finally, this provision is curious because so many of the "forbidden" uses of exempt small issues were still apparently allowed after TEFRA under the exempt facilities exemption, which had no specific volume limitation. ${ }^{129}$ "Sports facilities" and "convention or trade show facilities" have been exempt categories under that provision since the original 1968 Act. ${ }^{130}$ Thus elimination of small issue exemption for golf courses, skating facilities, racquetball courts, and racetracks ${ }^{131}$ would seem little more than an empty gesture, since such facilities can continue to be financed through tax-exempt IDB's. Legislative history does little to explain this apparent anomaly.

One possible interpretation comes from IRS attribution of a public purpose requirement to exempt-facility bonds but not to small issue bonds. Service regulations require that proceeds of exempt-facility bonds be used in a manner consistent with a public purpose; this includes a requirement that the financed facility be open to the general public. ${ }^{132}$ No such requirement is imposed by the IRS on the use of proceeds of small issues. ${ }^{133}$ It is thus possible that this small issue exclusion was designed primarily to prevent the use of tax-exempt financing for facilities which are not open to the general public.

In this regard, it is interesting to note that DEFRA section 627, which withholds tax-exemption from bonds used to finance certain facilities, contains what seem to be logical extensions of these TEFRA provisions in denying exemption to bonds "used to provide any airplane, skybox, or other private luxury box, any health club facility, any facility primarily used for gambling, or any store the principal business of which is the sale of alcoholic

127. Prior to TEFRA, the only limits on the uses to which small issues could be put were the "trade or business" and "security interest" requirements of I.R.C. $\$ 103(\mathrm{~b})(2)$ (Lawyers Co-op. 1984 ), the prohibition on "arbitrage bonds" of $\$ 103(\mathrm{c})$, and the specific provision that small issue proceeds "are to be used (i) for the acquisition, construction, reconstruction, or improvement of land or property of a character subject to the allowance for depreciation, or (ii) to redeem part or all of a prior issue which was issued for purposes described in clause (i) or this clause," id. $\$ 103(\mathrm{~b})(6)(\mathrm{A})$.

128. At a national level, many projects which are attractive locally may not appear to serve a "public purpose." This is especially true of projects whose "public purpose" is economic development or job creation: to the extent that they create external benefits in their location, they serve a local public purpose, but to the extent to which they merely attract jobs and industry which would otherwise have located elsewhere, they create no net externalities for the economy as a whole.

129. I.R.C. \& 103(b)(4) (Lawyers Co-op. 1984).

130. See id. \& $103(\mathrm{~b})(4)(\mathrm{B}),(\mathrm{C})$.

131. Id. $\& 103(\mathrm{~b})(6)(\mathrm{O})$.

132. Treas. Reg. $\$ 1.103-8(\mathrm{a})(2)(1972)$.

133. See supra note 80 . 
beverages for consumption off premises."134 Unlike TEFRA, however, DEFRA's provisions apply to all industrial development bonds, not just to small issues.

\section{The Small Issue Volume Cap}

DEFRA's one major provision aimed specifically at small issues is a volume cap imposed on owners and principal users of facilities financed by small issues. Section 623 of DEFRA provides that no small issue exemption shall be allowed for an issue "if the aggregate authorized face amount of such issue allocated to any [owner or principal user] (when increased by the outstanding tax-exempt IDB's of such [person]) exceeds $\$ 40,000,000 . " 135$ The outstanding IDB's of an owner or user-a "test-period beneficiary"136_are calculated as its pro rata share of:

the aggregate face amount of all industrial development bonds the interest on which is exempt from tax...

(i) which are allocated to such beneficiary, and

(ii) which are outstanding at the time of such later issue (not including as outstanding any obligation which is to be redeemed from the proceeds of the later issue). ${ }^{137}$

This measure, which prevents large corporations from financing a large number of separated facilities with small issue obligations, seems to have been inspired by previous notorious uses of small issues to finance K-Mart stores, McDonald's restaurants, and other corporate chain operations. ${ }^{138}$

It should be noted that the cap is quasi-cumulative, in that the limit is based on all the test-period beneficiary's outstanding IDB's, not just its outstanding small issues. A potential IDB issuer may borrow up to $\$ 40$ million in small issues and then issue exempt facility bonds without running afoul of this limit, but the converse is not true: it may not issue any small issue obligations if, as a result, its total outstanding IDB's would exceed $\$ 40$ million. This asymmetry encourages borrowers contemplating both small issue and exempt facility borrowing (for different facilities) to issue the small issue obligations first. ${ }^{139}$ Potential market distortions which might result are, however, probably minimal and, in any case, temporary to the extent that the small issue sunset legislation remains in place.

Far more troubling is the possibility, inherent in the wording of this section, that loss of tax exemption may be applied retrospectively. New Code subsection $103(b)(15)$ provides, as the general rule, that the small issue exemption "shall not apply to any issue if" the total IDB debt of the owner or principal user of the facility is excessive. ${ }^{140}$ Even if the measure is held

134. I.R.C. \& 103(b)(18) (Lawyers Co-op. Supp. 1985).

135. Id. \& $103(\mathrm{~b})(15)(\mathrm{A})$.

136. See infra notes $142-44$ and accompanying text.

137. I.R.C. $\$ 103($ b)(15)(B) (Lawyers Co-op. Supp. 1985).

138. See supra notes 97-98 and accompanying text.

139. This "planning opportunity" is discussed by Arkuss, supra note 25, at 16, col. 1.

140. I.R.C. \& 103(b)(15)(A) (Lawyers Co-op. Supp. 1985). 
applicable only to bonds issued after its effective date (December 31, 1983), ${ }^{141}$ there remains a risk of retroactive application. This is so because of the way that "test-period beneficiary"-a new construct of the Act-is defined.

A test-period beneficiary (TPB) is a person "who was an owner or a principal user of facilities being financed by the issue at any time during the three-year period beginning on the later of (i) the date such facilities were placed in service, or (ii) the date of the issue." 142 Persons related to TPB's are also test-period beneficiaries. ${ }^{143}$ Obviously one bond issue can have more than one $\mathrm{TPB}$-at least two, if the financed facility has one owner and a different principal user, and potentially many more since related persons; coownership; subdivision of facilities among different principal users; and sale, lease, and assignment within the three year period would all increase the number of TPB's. Each and every one of the originally identifiable TPB's must initially be able to meet the $\$ 40$ million limit at the time the bonds are issued in order for them to be tax-exempt. ${ }^{144}$

The problem of retroactivity arises when new TPB's enter the picture before the three-year period is up. If the new beneficiaries are at that time ineligible, the bondholders risk loss of exemption on future interest payments, at least. If the new beneficiaries were ineligible at the time the bonds were originally issued, there seems to be a possibility that tax exemption of the issue $a b$ initio is lost, raising a spectre of retroactive tax due on interest payments already received. Until some of these issues are settled by litigation or, preferably, congressional amendment, the tax status of small issue bonds will remain clouded during the relevant three-year period.

There are other difficulties in interpreting this section as well. The status of refunding issues is questionable.145 Allocating the volume of new borrowing for purposes of the cap may also be troublesome in some cases. It is apparent that both the owner and a nonrelated principal user can be charged with the full amount of an issue ${ }^{146}$-a curious result is that more volume can be allocated than was actually borrowed ${ }^{147}$ - but allocation among co-owners and among principal users may be difficult, particularly when complicated by timing considerations as in cases of sublease or sale, or where serial obligations or sinking funds are employed.

The uncertainty which these provisions engender makes new small issues risky for both issuers and buyers. The risk presented by possible loss of tax exemption, especially, is likely to make small issues more difficult to market.

141. See Pub. L. No. 98-369, §631(c)(1), 98 Stat. 494, 935, reprinted in notes following I.R.C. $\$ 103$ (Lawyers Co-op. Supp. 1985). But see id. $\$ 631$ (c)(3), 98 Stat. at 936, reprinted in notes following I.R.C. $\$ 103$ (Lawyers Co-op. Supp. 1985) (exception for issues where a binding contract or construction was undertaken before Oct. 19, 1983).

142. I.R.C. \& 103(b)(15)(D) (Lawyers Co-op. 1985).

143. Id. $\$ 103(\mathrm{~b})(15)(\mathrm{E})$.

144. See generally Arkuss, supra note 25, at 16, col. 1 .

145. See id. at cols. 2-3.

146. See I.R.C. \& 103(b)(15)(C)(i) (Lawyers Co-op. Supp. 1985).

147. Arkuss, supra note 25 , at 16 , col. 1 . 
It appears that this provision, though perhaps not designed to have this effect, constitutes yet another measure which will to some extent serve to curtail the use of small issues during their sunset period.

\section{Umbrella Bonds and Other Measures}

Two TEFRA provisions for small issues run counter to the general trend in that they expand, rather than contract, the tax-exempt use of these bonds. Each provision reverses previous Treasury interpretation of earlier law. One is a rather limited provision excluding certain kinds of capitalized research expenditures in calculating the "aggregate authorized face amount" subject to the $\$ 10$ million maximum. ${ }^{148}$ The other provides separate treatment for purposes of calculating aggregate authorized face amount of issues used to finance a single facility when different portions of the facility will be utilized by different principal users. This latter measure has proved somewhat controversial.

TEFRA section 214(a) ${ }^{149}$ deals with this problem of multiple issues, or "umbrella bonds," which arises when separate small issues are marketed together or have the same collateral. Departing somewhat from earlier Revenue Rulings, ${ }^{150}$ in 1981 the IRS articulated a rule that multiple lots would be considered a single issue for purposes of Code section 103(b) if

148. TEFRA section 214(d) provides that research expenditures for supplies, wages, and similar operating research costs may be excluded from the figure for capital expenditures which must be included in calculating the aggregate authorized face amount subject to the $\$ 10$ million limitation of Code section 103(b)(6)(D). I.R.C. $\$ 103(\mathrm{~b})(6)(\mathrm{F})$ (Lawyers Co-op. 1984). These costs may be deducted as expenses under $\$ 174$, which permits elective deduction or amortization of research and experimental expenditures. Id. § $174(\mathrm{a})$; see also id. $\$ 44 \mathrm{~F}(\mathrm{~b})(2)(\mathrm{A})$ (describing these research expenditures). If deduction of these costs is elected, they are excluded from aggregate authorized face amount as well. Id. $\$ 103(\mathrm{~b})(6)(\mathrm{F})(\mathrm{iv})$ (Lawyers Co-op. Supp. 1985).

Treasury regulations provide that capital expenditures must include, for purposes of determining compliance with the $\$ 10$ million limit, all expenditures "properly chargeable to the capital account of any person .... without regard to any rule of the Code which permits expenditures properly chargeable to capital account to be treated as current expenses." Treas. Reg. \&1.103-10(b)(2)(ii)(e) (1972). Ruling that section 174 expenditures were "properly chargeable to . . . capital account," the IRS in 1977 held that they were capital expenditures for purposes of section 103(b)(6)(D). Rev. Rul. 77-27, 1977-1 C.B. 23. This provision of TEFRA reverses that ruling.

Like other small issue provisions of TEFRA, this measure originated in the Senate Finance Committee, whose accompanying Report cites as reasons for the change the Committee's belief "that research and development expenditures should be encouraged." S. REP. No. 494, 97th Cong., 2d Sess. 182, reprinted in 1982 U.S. CodE. Cong. \& AD. News 781, 942. The Committee also believed "that such a rule is consistent with the purpose of the $\$ 10$ million limitation of restricting the size of projects which may be financed with small issue bonds because the size of a project is not affected by the amount of research and development expenses for supplies and salaries." Id. The Senate Committee did not add, although it could have, that research wages and supplies may be viewed as "properly chargeable to capital" by the Service, but they are not so viewed by the accounting profession. FASB Statement No. 2 requires expensing, rather than capitalization, of such expenditures. See Financial Accounting Standards Board, Statement of Financial Accounting Standards No. 2: Accounting for Research and Development Costs (1974).

149. 1.R.C. \& $103(\mathrm{~b})(6)(\mathrm{K})$, (L) (Lawyers Co-op. 1984).

150. In TEFRA, Congress appears to have restored the approach taken in these earlier rulings, although it may have gone further in facilitating "umbrella" consolidations. See Rev. Rul. 74-380, 1974-2 C.B. 32 (different issues, issued on the same date, pursuant to a single resolution adopted by a single political entity, to finance distinctly different parts of a single manufacturing facility to be leased to a single corporation, to be treated as separate bond issues provided the security for each 
(1) the obligation will be sold at substantially the same time, (2) the obligations will be sold pursuant to a common plan of marketing, (3) the obligations will be sold at substantially the same rate of interest, and (4) a common or pooled security will either be used or available to pay debt service on the obligations. ${ }^{151}$

This rule did not meet with congressional approval. In 1981 Congress imposed a moratorium on its enforcement, ${ }^{152}$ and in TEFRA it reversed the rule for all cases except where proceeds of the set of issues were to be used to finance facilities in more than one state or facilities "which have, or will have, as the same principal user the same person or related persons." 153

The provision originated in the Senate, ${ }^{154}$ but the accompanying Senate Report has no explanation of it. In defense of the measure, it may be said to promote efficient marketing of small issue IDB's, ${ }^{155}$ perhaps especially if it facilitates public, competitive offerings of the combined lots. ${ }^{156}$ Indeed, the ostensible purpose of the small issue exemption to assist small businesses may be better served by this provision, and to the extent that these are somewhat riskier firms, less able to attract financing on their own than larger enterprises which have been using small issue IDB's, the feature may promote economic development and job creation. ${ }^{157}$ As is generally true of small issue exempt bonds, however, the benefits of this provision are by no means restricted to small firms and underdeveloped regions. The measure was widely criticized for permitting evasion of the $\$ 1$ million "clean limit" through judicious allocation of parts of a facility to different principal users. ${ }^{158}$ For example, an office building could be constructed using $\$ 1$ million worth of bonds for each floor, and the bonds would meet the requirements for small issue exemption as long as each floor was rented or sold to a different user. ${ }^{159}$

bond issue was kept separate and distinct); Rev. Rul. 78-159, 1978-1 C.B. 27 (a state's simultaneous issuance of separate series of IDB's, each series in the amount of $\$ 1$ million, under separate bond indentures and with security for each series independent of that for each of the other series, to be treated as separate, exempt "small issues"); Rev. Rul. 77-55, 1977-1 C.B. 18 (similar to id. but with all issues maintained by a single trustee under a single pooled security: bonds treated as part of a single issue, hence not exempt).

151. Rev. Rul. 81-216, 1981-2 C.B. 21 . Subsequently proposed amendments to Reg. $\$ \S 1.103-7$ and 1.103-10 were substantially similar. See 46 Fed. Reg. 50,014 (1981).

152. Appropriations Act of Dec. 15, 1981, Pub. L. No. 97-92, \& 112(a)(1), (2), 95 Stat. 1183 , 1194-95.

153. I.R.C. \& 103(b)(6)(K), (L) (Lawyers Co-op. 1984). "Related persons" are defined for purposes of this section to include franchises, see id. $\$ 103(\mathrm{~b})(6)(\mathrm{L})$, a definition possibly aimed at the "McDonald's problem," although it provides only a limitation on franchise use of umbrella bonds and would be ineffective against franchise construction in different locations.

154. H.R. Rep. No. 760, 97th Cong., 2d Sess. 522, reprinted in 1982 U.S. Code Cong. \& Ad. News 781, 1297-98.

155. Small issues independently financed through banks generally carry low transaction fees, but their yields are higher than the yields on larger, rated (and publicly placed) issues. See SMall Issue, supra note 47 , at 24-25.

156. See, e.g., Kessel, $A$ Study of the Effects of Competition in the Tax-Exempt Bond Market, $79 \mathrm{~J}$. Pol. ECON. 706, 717-23 (1971).

157. See SMALI Issue, supra note 47, at 51 (whereas "[i]n general, small issue IRB financing is available only to creditworthy firms," the umbrella issues may provide access to tax-exempt financing for riskier firms).

158. See, e.g., 19 Tax Notrs 442 (letter of Rep. Frenzel) (1983).

159. See Letter Ruling 8114070 (1981), discussed in Private Letter Rulings, 55 J. TAx 52 (1981). 
Congress plugged this loophole in DEFRA, ${ }^{160}$ enacting a rule requiring aggregation of issues used with respect to a single project:

[Two] or more issues part or all of which are to be used with respect to a single building, an enclosed shopping mall, or a strip of offices, stores, or warehouses using substantial common facilities shall be treated as [one] issue (and any person who is a principal user with respect to any of such issues shall be treated as a principal user with respect to the aggregated issue). ${ }^{161}$

The accompanying House Committee Report adds that "[i]n order for there to be common facilities, the two facilities used by the different users generally must be continguous," citing "common heating, cooling and other facilities" and "common entrances, plazas, malls, lobbies, parking, elevators, and stairways" as features which would trigger application of the single-issue rule. ${ }^{162}$

The principal effect of this measure is to deny tax-exempt financing for large office buildings and shopping malls. Although it significantly restricts the scope of the TEFRA provision, DEFRA does not explicitly overrule it. Presumably instances will still be found of umbrella bonds using a "common or pooled security" which is not a set of contiguous facilities. These small issues remain eligible for separate treatment after DEFRA.

\section{IV}

\section{Limiting Private Activity Bonds}

In addition to measures directed at small issues or at other specific types of IDB's, TEFRA contains several broader provisions which can be expected to restrict the issuance of tax-exempt IDB's generally. The most obvious limitation on IDB issuance, however, is contained in DEFRA. Indeed, DEFRA marks a major shift in approach to limiting tax-exempt debt issuance, in making explicit the congressional intent to restrict the volume of outstanding tax-exempt private activity debt.

The DEFRA volume cap ${ }^{163}$ imposes a general limit on the amount of taxexempt private activity debt that can be issued in a given year by a state or geographical authority. Supplemented by the per-user limit for small issues, already discussed, ${ }^{164}$ this cap is the first explicit restriction of tax-exempt IDB's based on aggregate amount issued by the issuing government, rather than on the category or amount borrowed to finance an individual project. It is further supplemented by provisions eliminating tax-exemption for consumer loan bonds ${ }^{165}$ and for several specific kinds of IDB's, notably bonds

160. Both House and Senate proposed versions of DEFRA contain the substance of this provision. H.R. Rep! No. 861, 98th Cong., 2d Sess. 1211, reprinted in 1984 U.S. Code Cong. \& AD. News No. 6B, 751, 1205.

161. I.R.C. \& 103(b)(6)(P) (Lawyers Co-op. Supp. 1985).

162. H.R. Rep. No. 432, Pt. II, 98th Cong., 2d Sess. 1694, reprinted in 1984 U.S. Code ConG. \& AD. News, No. 6B, 3, 623 .

163. See infra notes $168-99$ and accompanying text.

164. Supra notes $135-47$ and accompanying text.

165. See infra notes $222-36$ and accompanying text. 
used to finance purchase of land or existing property ${ }^{166}$ and some IDB's "directly or indirectly guaranteed" by the federal government. ${ }^{167}$

\section{A. Limitation on Aggregate Amount of Private Activity Debt}

Section 621 of DEFRA ${ }^{168}$ imposes a per-state limitation on the annual volume issued of new "private activity" bonds, defined generally for purposes of the section as tax-exempt IDB's and student loan bonds. ${ }^{169}$ Only IDB's and student loan bonds are subject to the section 621 volume cap, although MHSB's and veterans mortgage bonds are subject to a separately calculated limitation. ${ }^{170}$ Tax-exempt bonds issued on behalf of schools, hospitals, and other section $501(\mathrm{c})(3)$ charitable organizations, which are sometimes considered to be "private activity" debt, are not included in the category for the purpose of volume limitation. ${ }^{171}$

Private activity issues do not include IDB's used to finance multifamily housing projects, which are specifically excepted. ${ }^{172}$ The House Committee considered these projects to be particularly dependent on tax-exempt financing and singled them out for favorable treatment in this and several other portions of the Act. ${ }^{173}$ Also excepted are IDB's financing convention facilities and "airports, docks, wharves, mass commuting facilities [or related] storage or training facilities" (but specifically not parking facilities) that are owned by "or on behalf of" a government unit.174 Such facilities leased to private users by governmental owners may qualify, regardless of the length of their lease;175 however, the lease may not have "significant front end loading,"176 which might be tantamount to purchase by the private user, and the lessee must bind itself and its successors under the lease by an irrevocable election not to claim depreciation or investment tax credit on the property. ${ }^{177}$ The House Committee explanation of this exception is that these facilities are "large, one-time projects which may be particularly difficult to finance under a volume ceiling." 178

166. See infra notes 206-19 and accompanying text.

167. See infra notes 237-60 and accompanying text.

168. I.R.C. \& 103(n) (Lawyers Co-op. Supp. 1985).

169. Id. \& 103 (n)(7)(A), (8).

170. See id. \& 103A(g) (Lawyers Co-op. 1984 \& Supp. 1985).

171. The House Committee believed that these organizations "should continue to benefit from tax-exempt financing without being forced to compete with private businesses. This is consistent with the general treatment of these organizations, which are exempt from Federal taxes and are (in most cases) entitled to receive tax-deductible contributions." H.R. REP. No. 432, Pt. II, 98th Cong., 2d Sess. 1684, reprinted in 1984 U.S. Code Cong. \& AD. News No. 6B, 3, 613.

172. I.R.C. \& 103(n)(7)(B) (Lawyers Co-op. Supp. 1985).

173. H.R. Rep. No. 432, Pt. II, 98th Cong., 2d Sess. 1684, reprinted in 1984 U.S. Code Cong. \& AD. NEWS, No. 6B, 3, 613 .

174. I.R.C. $\& 103(\mathrm{n})(7)(\mathrm{C})(\mathrm{i})$, (ii) (Lawyers Co-op. Supp. 1985).

175. Id. \& $103(\mathrm{n})(7)(\mathrm{C})(\mathrm{iii})$.

176. Id. \& $103(\mathrm{n})(7)(\mathrm{C})(\mathrm{iv})$.

177. Id. \& $103(\mathrm{n})(7)(\mathrm{C})(\mathrm{iii})$.

178. H.R. Rep. No. 432, Pt. II, 98th Cong., 2d Sess. 1684, reprinted in 1984 U.S. Code Cong. \& AD. NEws No. $6 B, 3,613$. 
Another exception is made for refunding issues, used within 180 days of their date of issue to retire outstanding tax-exempt debt, to the extent that the new bonds issued do not exceed the volume of debt they are issued to replace. ${ }^{179}$ In the case of student loan bonds, there is a further condition that the refunding obligations' maturity date may not be later than the maturity date of the refunded issue and not later than seventeen years after the date on which the refunded obligations were issued. ${ }^{180}$ Most IDB advance refundings are not tax-exempt, but those which are may also utilize this exemption. ${ }^{181}$

The basic geographical unit for the volume cap is the state, and the statewide ceiling on annual issuance is based on the state population: $\$ 150$ per state resident or $\$ 200$ million, whichever is larger. ${ }^{182}$ States may enact their own formula for allocating this ceiling amount, ${ }^{183}$ and the Act provides state governors with interim authority to direct such allocation prior to their state legislatures' having had an opportunity to consider it. ${ }^{184}$ Absent such direction, DEFRA allocates $50 \%$ of the cap to state agencies, with the remaining 50\% divided among local agencies and authorities on a per capita basis. ${ }^{185}$ Transitional rules permit a larger ceiling in 1984 for states which had debt in excess of the ceiling amount in $1983 .{ }^{186}$ After 1986 , the $\$ 150$ per capita limit is reduced to $\$ 100$, "to reflect the scheduled expiration of the small issue exception." 187

The volume cap creates a need for some priority ranking system within those states and authority districts for which the cap is a meaningful constraint. In any given year, private activity bonds issued after the ceiling limit has been passed will simply not be tax-exempt. ${ }^{188}$ Hence the alternative to explicit prioritizing is rationing by the "first come, first served" method. Such allocation by race to the bond authority, of course, is unlikely to provide

179. I.R.C. $\$ 103(n)(7)(D)$ (Lawyers Co-op. Supp. 1985); see H.R. REP. No. 861, 98th Cong., 2d Sess. 1209, reprinted in 1984 U.S. Code Cong. \& AD. News No. 6B, 751, 1203.

180. I.R.C. \& 103(n)(7)(D) (Lawyers Co-op. Supp. 1985).

181. DEFRA repealed exemption for advance refunding for public facilities, Pub. L. No. 98-369, $\$ 628(\mathrm{~g}), 98$ Stat. 494, 932. Advance refunding for multifamily residential rental property is still permitted after DEFRA.

182. I.R.C. $\$ 103(\mathrm{n})(4)$ (A) (Lawyers Co-op. Supp. 1985). The $\$ 200$ million alternative was added by the Senate out of concern for low population states. See 130 ConG. REc. S8373 (daily ed. June 27, 1984) (statement of Sen. Dole). Compare I.R.C. \& 103(n)(4)(A) (Lawyers Co-op. Supp. 1985) with H.R. Rep. No. 432, Pt. II, 98th Cong., 2d Sess. 1683-84, reprinted in 1984 U.S. Code Cong. \& Ad. News No. 6B, 3, 611-12.

183. I.R.C. \& 103(n)(6)(A) (Lawyers Co-op. Supp. 1985).

184. Id. \& $103(\mathrm{n})(6)(\mathrm{B})$.

185. Id. $\$ 103(\mathrm{n})(2)$, (3). Special provision is made to assure that constitutional home rule cities in Illinois receive their per capita allotment. Id. \& 103(n)(5), (6)(C); H.R. REP. No. 432, Pt. II, 98th Cong., 2d Sess. 1688, reprinted in 1984 U.S. Code Cong. \& AD. News No. 6B, 3, 617. An exception from the ceiling is provided for up to $\$ 30$ million of anticipated borrowing for a Clayton, Delaware, regeneration plant. Pub. L. No. 98-369, \& 632(c), 98 Stat. 494, 938.

186. I.R.C. \& $103(\mathrm{n})(4)$ (B) (Lawyers Co-op. Supp. 1985); see H.R. REP. No. 432, Pt. II, 98th Cong., 2d Sess. 1684, reprinted in 1984 U.S. Code Cong. \& AD. News No. 6B, 3, 613. Rev. Proc. 8485, 1984-53 I.R.B. 16, provides issuers with a list of ceiling limitations for calendar year 1984.

187. I.R.C. $8103(n)(4)$ (C) (Lawyers Co-op. Supp. 1985); H.R. REP. No. 861, 98th Cong., 2d Sess. 1199, reprinted in 1984 U.S. Code Cong. \& AD. News No. 6B, 751, 1193; see H.R. Rep. No. 432, Pt. II, 98th Cong., 2d Sess. 1686, reprinted in 1984 U.S. CODE Cong. \& AD. NEws No. 6B, 3, 615.

188. See I.R.C. \& 103(n)(1) (Lawyers Co-op. Supp. 1985). 
optimal use of IDB's for the benefit of the community. Even where there is an explicit rationing calculated to maximize social good, however, the simple fact that rationing is required is likely to produce concomitant uncertainty for project developers and backers about whether, and when, tax-exempt financing will be available.

This uncertainty is probably exacerbated by a provision permitting carryover of unused cap only for specific projects, for which election must be made by the issuing authority before the end of the year for which the full cap is not utilized. ${ }^{189}$ The carryforward can only apply to student loan bonds and to bonds financing "exempt facilities" and industrial parks. ${ }^{190}$ The election, once made, is irrevocable and restricts tax-exempt debt financing of the "carryforward project" over the next three years (six years for air or water pollution control facilities) to the amount of carryforward elected. ${ }^{191}$ This provision widens the range of choices to be made by those responsible for allocating available tax-exempt volume, for the tradeoff in any given year includes not only possible alternative uses for debt to be issued in that year but also projects for which debt may be issued within three, or even six, years into the future. For project managers, the carryforward increases the potential number of competitors for tax-exempt financing allocation; it also may at times require a decision whether to seek (or accept) carryforward status, with its concomitant risk that more tax-exempt financing will be required in the future than was allocated to it at the time of election, or to gamble that they will be able to obtain exemption for each new borrowing during the years ahead.

The need for allocation rationing, especially with regard to year-end election, can be expected to enhance the responsibility and, concomitantly, the power of the official or officials who are charged with this function. ${ }^{192}$ Perhaps for this reason, the volume cap legislation requires that such officials execute "no-bribe" certificates, attesting "under penalty of perjury" that allocations were not made in consideration of any payment, gift, or campaign contribution. ${ }^{193}$ In addition to the perjury penalty, willful allocation of cap in consideration of such payment subjects the official to criminal penalty "to the same extent as if such allocation were a willful attempt to evade tax."194 "It is interesting to note," writes one observer, "that while Congress permits states to determine their own allocation procedures, it felt compelled to inject a perjury penalty into the process." 195 One might posit further that this certification requirement, coupled with the TEFRA rule mandating

189. Id. \& $103(\mathrm{n})(10)(\mathrm{A}),(\mathrm{B})$.

190. Id. \& $103(\mathrm{n})(10)(\mathrm{E})$.

191. Id. \& 103(n)(10)(B), (C), (D).

192. "Most states will probably designate a single official or agency as the state's allocator of cap." Arkuss, supra note 25, at 15, col. 4.

193. I.R.C. \& 103(n)(12)(A) (Lawyers Co-op. Supp. 1985).

194. Id. \& $103(\mathrm{n})(12)(\mathrm{B})$. Willful attempt at tax evasion is a felony, for which the penalty, "in addition to other penalties provided by law," is a fine not more than $\$ 100,000(\$ 500,000$ for corporations) or imprisonment for up to five years, or both. Id. $\$ 7201$ (Lawyers Co-op. Supp. 1985).

195. Arkuss, supra note 25, at 16, col. 1 . 
authorization of IDB's by elected officials or by referendum, ${ }^{196}$ reflects a basic congressional distrust of Industrial Development Authority officials which, based on some of the known small issue abuses already discussed, ${ }^{197}$ might not be wholly unreasonable. (No such motivation, however, is evident in the legislative history, which provides no explanation at all for the certification requirement.)

It is self-evident that the purpose of the volume cap was to reduce the overall level of private activity borrowing, and the legislative history links this purpose to the goal of eliminating revenue leakage. ${ }^{198}$ The extent to which these goals are in fact achieved will not, however, be immediately apparent. For one thing, the TEFRA reporting requirements ${ }^{199}$ have not been in place long enough to get a secure sense of what private activity debt was a "normal" level prior to institution of the volume cap. Moreover, although the volume cap went into effect in 1984 , because of the transition rules its impact is not likely to be fully evident until 1985, if then. One immediate response to the transition rules, predictably, will be a rush to borrow early before the cap takes full effect. To the extent that such accelerated borrowing replaces debt which would otherwise be issued in 1985 or later, any estimate of the cap's effect based on observed reduction after 1985 in tax-exempt borrowing may be somewhat distorted.

\section{B. Further DEFRA Limitation}

In addition to the overall volume cap, DEFRA eliminates tax exemption for many bonds which are guaranteed "directly or indirectly" by the federal government. ${ }^{200}$ It creates a new category of bonds-consumer loan bondsfor which tax exemption is denied. ${ }^{201}$ It also continues the work of TEFRA in restricting further the kinds of projects for which tax-exempt financing is available. Eliminated in DEFRA are obligations used to purchase farm land, large quantities of land for other purposes, or existing buildings, along with several very specific prohibited uses. ${ }^{202}$

196. See infra notes 265-72 and accompanying text.

197. Supra notes $96-98$ and accompanying text.

198. The legislative history of the Act states:

The rapid growth of private activity bonds is a source of concern for several reasons. First, the mounting volume of private activity tax-exempt bonds has resulted in an increasing revenue loss (a projected $\$ 8.5$ billion for 1983 from identifiable private activity bonds). Because a substantial portion of the benefits of tax-exemption flows to the investor, tax-exempt bonds are a relatively inefficient means of providing a subsidy.

Second, the committee is concerned that the expanding volume of private activity bonds has inflated tax-exempt interest rates, thereby increasing the costs of State and local borrowing for traditional public purposes .... .

Finally, the availability of tax-exempt financing for certain types of projects . . . [may] divert investment capital away from its most productive uses.

H.R. Rep. No. 432, Pt. II, 98th Cong., 2d Sess. 1683, reprinted in 1984 U.S. Code Cong. \& Ad. News No. $6 \mathrm{~B}, 3,612$.

199. See supra notes $107-13$ and accompanying text.

200. See infra notes 237-61 and accompanying text.

201. See infra notes $222-36$ and accompanying text.

202. See infra notes 206-21 and accompanying text. 
1. Restrictions on IDB Use. Like TEFRA, which singled out certain types of expenditures for which tax-exempt small issue financing would not be available, ${ }^{203}$ DEFRA section $627^{204}$ denies tax exemption generally to several different kinds of IDB's. No logical or historical connection among these excluded categories is stated in the Act or in the legislative history, ${ }^{205}$ although one might suspect that all these measures were enacted to some extent in response to perceived previous abuse. These provisions add three new subparagraphs to Code section 103(b), the section dealing explicitly with IDB's.

New section 103(b)(16) creates a "limitation on use for land acquisition," whereby exempt purpose, industrial park, or small issue IDB's are not exempt if:

(i) any portion of the proceeds of such issue are to be used (directly or indirectly) for the acquisition of land (or an interest therein) to be used for farming purposes, or

(ii) 25 percent or more of the proceeds of such issue are to be used (directly or indirectly) for the acquisition of [any other] land. . . .206

There is an exception for land acquired by a public agency "in connection with an airport, mass transit, or port development project . . . for a noise abatement, wetland preservation, future use, or other public purpose."207 The exception only applies, however, if "there is no other significant use of such land."208

Some aspects of this exception are rather troubling. The statute would apparently exempt IDB's issued to acquire land for wetland preservation, for example, if issued by an airport authority in connection with building a nearby runway but not if issued to finance an industrial park located next to preservation land-a seemingly illogical distinction. Moreover, the requirement that there be no "other significant use" apparently encourages waste, as it implies that land set aside for future use will not meet the requirements of this exception if it is cultivated or put to a timber crop during the interim. This latter problem, at least, is susceptible to administrative alleviation. The singling out of transportation agencies as designated protectors of the environment is not, however, but presumably regulations will eventually clarify the application and interpretation of this provision.

New Code section 103(b)(17) provides that IDB's are not tax exempt "if any portion of the proceeds of [the] issue is to be used for the acquisition of any property... unless the first use of such property is pursuant to such

203. See supra notes 125-34 and accompanying text.

204. I.R.C. $\$ 103($ b)(16)-(18) (Lawyers Co-op. Supp. 1985).

205. The legislative history of this section is found principally at H.R. REP. No. 432, Pt. II, 98th Cong., 2d Sess. 1691-93, reprinted in 1984 U.S. Code Cong. \& AD. News No. 6B, 3, 620-22; and at H.R. Rep. No. 861, 98th Cong., 2d Sess. 1207-09, reprinted in 1984 U.S. Code Cong. \& AD. NEws No. $6 \mathrm{~B}, 751,1201-03$. Neither report indicates any underlying rationale for the provisions of this section.

206. I.R.C. $\$ 103(\mathrm{~b})(16)$ (A) (Lawyers Co-op. Supp. 1985). In the case of an industrial park, the applicable percentage for $\$ 103$ (b)(16)(A)(ii) is $50 \%$ rather than $25 \%$. Id.

207. Id. \& $103(\mathrm{~b})(16)(\mathrm{C})(\mathrm{i})$.

208. Id. \& 103(b)(16)(C)(ii). 
acquisition."209 This rule is more stringent than that of the preceding subsection dealing with acquisition of land, in that these bonds are ineligible if any portion of the issue is used to finance existing property (as opposed to $25 \%$ ) and because the rule is made applicable to refunding bonds. ${ }^{210}$ Denial of tax exemption for refunding issues will impose a windfall loss on some previous IDB users, notably those who borrowed during the peak interest rate period of the 1970's, reasonably anticipating that they could refund their debt later. When the basis for such denial is their previous use of debt for a purpose which was then perfectly acceptable, the new provision seems harsh. The long-lived nature of buildings and other property covered by this section, however, makes it economically feasible to finance this same collateral through refundings over a very long period of time; and it was probably to plug this rather obvious potentially long-lived loophole that refunding bonds were included.

An exception is made to the general rule when rehabilitation expenditures by the person acquiring a building amount to at least $15 \%$ of the cost of acquisition. ${ }^{211}$ The expenditures, "properly chargeable to capital account," must be made within two years of the date of issue or acquisition, whichever is later. ${ }^{212}$ Equipment is counted as part of the building. For facilities other than buildings the rehabilitation expenditure must equal or exceed $100 \%$ of the acquisition cost for the exception to apply.213 The reason for the distinction is not apparent, nor is the basis for the selection of $100 \%$ rather than $75 \%$ or $90 \%$ or some other percentage. It does seem clear, however, that the general policy underlying both these sections of DEFRA is to deny tax exemption generally where no new capital formation-roughly, no increase in net social wealth-will result from the expenditure financed by the debt issue. In light of that policy, this exception for rehabilitated property clearly makes sense.

There is one further exception, both to this section and to the rule denying tax exemption for financing acquisition of farm land. The "first-time farmer" exception permits tax exemption for bonds assisting individuals to acquire farm land and buildings ${ }^{214}$ where the individual "is a first-time farmer, who will be the principal user of such land [for farming purposes] and who will materially and substantially participate . . . in the operation of such farm."215 This last requirement, according to the accompanying House Committee Report, "is intended to restrict availability of the exception to individuals who

209. Id. \&103(b)(17)(A).

210. Id. \& $103(\mathrm{~b})(16)(\mathrm{A})$.

211. Id. \& $103(\mathrm{~b})(17)(\mathrm{B})$.

212. Id. \& $103(\mathrm{~b})(17)(\mathrm{C})$.

213. Id. \& $103(\mathrm{~b})(17)(\mathrm{B})$.

214. Code section 103(b)(16)(B)(i) permits tax exemption for bonds used to assist first-time farmers in buying land and also exempts these bonds from the provisions of $\$ 103(b)(17)$ as long as the financed facilities, acquired within one year for no more than $\$ 250,000$, are located on the farm land and used in farming. Id. \& $103(\mathrm{~b})(16)(\mathrm{B})(\mathrm{i})$.

215. Id. \& $103(\mathrm{~b})(16)(\mathrm{B})(\mathrm{ii})(\mathrm{II})$. 
generally will perform substantial physical work in the farming operation."216 A first-time farmer is defined in the Act, roughly, as an individual who has not previously worked a farm in which he had an ownership interest ${ }^{217}$ or whose previously held farm was very small. ${ }^{218}$ Prior ownership of an interest in a farm which the individual did not materially participate in operating does not disqualify him from "first-time farmer" status, so that children of farmers who own some share in their parents' farm are not necessarily ineligible under this provision. ${ }^{219}$

New section 103(b)(18) of the Code contains a prohibition on the use of IDB's to finance skyboxes, airplanes, health club facilities, gambling facilities, and liquor stores. ${ }^{220}$ With the exception of health club facilities, these categories all originated in the House. Rejected in the Conference Committee were Senate-proposed bans on tax-exempt financing for parking, doctors' and lawyers' offices, and nursing homes. ${ }^{221}$ Presumably these proposals represent a reaction to known or suspected abuse, or in the case of gambling facilities and liquor stores perhaps a bow to the Moral Majority. The text of the Act and its legislative history give no indication for the reasons underlying these provisions.

2. Consumer Loan Bonds. Consumer loan bonds are singled out for taxable status under DEFRA section $626,{ }^{222}$ which is noteworthy in that it creates the first new category of bonds subjected to a general rule of taxability since such a rule was imposed on IDB's in the late 1960's. ${ }^{223}$ These bonds are "used directly or to make or finance loans . . . to persons who are not exempt persons"224-that is, to borrowers other than governments and section

216. H.R. ReP. No. 432, Pt. II, 98th Cong., 2d Sess. 1693, reprinted in 1984 U.S. Code Cong. \& AD. News No. 6B, 3, 622 .

217. I.R.C. \& $103(\mathrm{~b})(16)(\mathrm{B})(\mathrm{iii})$ (Lawyers Co-op. Supp. 1985). "For purposes of this subparagraph, any ownership or material participation by an individual's spouse or minor child shall be treated as ownership and material participation by the individual." Id. Rev. Proc. 85-30, 1985-22 I.R.B. 8-21, provides issuers with a list of median farm size by county.

218. I.R.C. \& 103(b)(16)(B)(v) (Lawyers Co-op. Supp. 1985).

219. Similarly, the definition "permits individuals who have previously owned farm equipment and such real property improvements as sheds to house the equipment and have used those facilities as part of a farming operation involving only leased land to qualify as first-time farmers." H.R. REP. No. 432, Pt. II, 98th Cong., 2d Sess. 1693, reprinted in 1984 U.S. Code Cong. \& AD. News No. 6B, 3, 622.

220. I.R.C. $\$ 103(b)(18)$ (Lawyers Co-op. Supp. 1985). The prohibition on use of tax-exempt funds to finance skyboxes does not constitute denial of tax-exempt financing for facilities containing skyboxes: "[r]ather, no portion of the proceeds of the IDB may be used to provide any skybox." H.R. ReP. No. 432, Pt. II, 98th Cong., 2d Sess. 1693, reprinted in 1984 U.S. Code Cong. \& AD. News No. 6B, 3, 622 (also contains a detailed definition of what Congress intends shall be understood to be a skybox).

221. H.R. ReP. No. 861, 98th Cong., 2d Sess. 1208-09, reprinted in 1984 U.S. Code ConG. \& AD. NEws No. 6B, 751, 1202-03; 130 ConG. REC. S8379 (June 27, 1984) (remarks of Sen. Dole), reprinted in 1984 U.S. Code Cong. \& Ad. News No. 6B, at 1475.

222. I.R.C. \& 103(o) (Lawyers Co-op. Supp. 1985); Pub. L. No. 98-369, § 626(b), 98 Stat. 494, 927-28, reprinted in notes following I.R.C. $\$ 103$ (Lawyers Co-op. Supp. 1985).

223. Revenue and Expenditure Control Act of 1968, Pub. L. No. 90-364, 8 107, 82 Stat. 251, 26668 (codified as amended at I.R.C. \& 103(b) (Lawyers Co-op. 1984)).

224. I.R.C. \& 103(o)(2)(A) (Lawyers Co-op. Supp. 1985). 
501(c)(3) charitable organizations. ${ }^{225}$ It should be stressed that consumer loan bonds are not IDB's; in fact, IDB's are explicitly exempted from the provision. ${ }^{226}$

Under this section, consumer loan bonds are generally taxable, ${ }^{227}$ but there are, of course, a number of exceptions. In fact, in this section, the exceptions seem to have gotten out of hand. There are "excluded obligations": industrial development bonds, "qualified" student loan bonds (defined in the Act in considerable detail'228), and "qualified" mortgage and veterans' mortgage bonds (defined in Code section 103A ${ }^{229}$ ). ${ }^{230}$ There are also "excluded loans": loans enabling private persons to pay their taxes or to purchase taxable securities, to the extent permitted by arbitrage regulations. ${ }^{231}$ Certain MHSB's and refunding obligations are exempt, ${ }^{232}$ as are "certain bonds for renewable energy property," 233 specified refunding obligations of the Pennsylvania Higher Education Assistance Agency, ${ }^{234}$ and bonds issued by sixteen specifically named student loan programs up to designated amounts which are, for the most part, different for each program. ${ }^{235}$

The result of all these exceptions is a complicated and apparently toothless provision, in that it is not at all clear what kind of consumer loan bonds remain to which the Act does apply. The legislative history provides no guidance, since the measure originated in the Senate and was amended into the Act in Conference Committee without an accompanying report. ${ }^{236}$

3. Bonds Guaranteed by the Federal Government. Section 622 of DEFRA amends Code section 103(h) to provide that, in general, an "obligation shall not be

225. See id. $\$ 103$ (b)(3). DEFRA section 629(a) expands the category of "exempt persons" to include public utilities. Pub. L. No. 98-369, § 629(a), 98 Stat. 494, 932-33, reprinted in notes following I.R.C. § 103 (Lawyers Co-op. Supp. 1985).

226. I.R.C. \& 103(o)(2)(B)(ii) (Lawyers Co-op. Supp. 1985).

227. Id. \& $103(\mathrm{o})(1)$.

228. Id. $\$ 103(0)(3)$. Roughly, student loan bonds are qualified if operated under a program "of general application to which the Higher Education Act of 1965" applies, guaranteed by the federal government and eligible (unless barred solely because of tax exemption) for federal special allowance payments, as long as the program limits the amount which any student can borrow and the rate of interest which can be charged on such borrowing, and as long as the state program does not discriminate "on the basis of the location (in the United States) at which the educational institution is located." Id.

229. See id. \& $103 \mathrm{~A}(\mathrm{c})(1),(3)$.

230. Id. \& 103(o)(2)(B).

231. Id. \& $103(\mathrm{o})(2)(\mathrm{C})$.

232. Pub. L. No. 98-369, $\$ 626(\mathrm{~b})(3),(4), 98$ Stat. 494, 928, reprinted in notes following I.R.C.

$\$ 103$ (Lawyers Co-op. Supp. 1985).

233. Id. \& 626(b)(6), 98 Stat. at 928, reprinted in notes following I.R.C. \& 103 (Lawyers Co-op. Supp. 1985).

234. Id. $\$ 626$ (b)(2)(B), 98 Stat. at 927-28, reprinted in notes following I.R.C. $\$ 103$ (Lawyers Coop. Supp. 1985).

235. Id. \& 626(b)(2)(A), 98 Stat. at 927, reprinted in notes following I.R.C. \& 103 (Lawyers Co-op. Supp. 1985).

236. H.R. REP. No. 861, 98th Cong., 2d Sess. 1213-14, reprinted in 1984 U.S. Code Cong. \& AD. News No. 6B, 3, 751, 1207-08. 
[tax exempt] . . . if such obligation is federally guaranteed."237 The potential overbreadth of this section is troubling, particularly since tax exemption is explicitly denied where the obligation is guaranteed "directly or indirectly."238 As usual, however, there is a wide array of exceptions to the general rule.

There are three different ways in which a bond is held to be federally guaranteed and thus subject to tax under this section. First, there are direct guarantees: bonds are taxable if "the payment of principal or interest . . . is guaranteed (in whole or in part) by the United States (or any agency or instrumentality thereof)," or if a "significant portion" of the issue proceeds are guaranteed.239 Second, an obligation is federally guaranteed if a significant portion of the issue of which it is a part is "invested (directly or indirectly) in federally insured deposits or accounts."240 Finally, an obligation is guaranteed if "the payment of principal or interest on such obligation is otherwise indirectly guaranteed" by the federal government or one of its agencies. ${ }^{241}$ This last provision, of course, is the part most susceptible to a potentially overinclusive interpretation.

One purpose of section 622 of the Act is most apparent in the requirement that tax-exempt bonds stand to lose their tax-exempt status if the bond proceeds are deposited in federally insured deposits or accounts. Arbitrage laws in effect prior to enactment of DEFRA denied tax exemption to bonds used to acquire higher-yielding obligations, ${ }^{242}$ but no such restriction applied to bonds whose proceeds were deposited in banks. Since in recent years the prevailing rates of interest paid by banks have frequently exceeded the rates on tax-exempt debt issues, and since bank deposits and certificates are federally insured and thus equivalent in safety to Treasury obligations, the proceeds of a substantial number of bond issues in late 1982 and early 1983 were apparently used to buy certificates of deposit or were simply deposited into FDIC and FSLIC protected accounts rather than being invested in government debt instruments to which arbitrage restrictions would have applied. ${ }^{243}$ The rule barring tax exemption for bonds deposited in federally guaranteed bank accounts is thus a logical and probably necessary corollary to the general arbitrage regulations applying to tax-exempt organizations. ${ }^{244}$

Another reason for this measure is indicated in the accompanying House Committee Report. Not only does the availability of federally guaranteed taxexempt financing provide a potentially unfair "double subsidy for certain activities," but federally guaranteed tax-exempt bonds are more attractive to investors than either (taxable) Treasury obligations or (riskier)

237. I.R.C. \& 103(h)(1) (Lawyers Co-op. Supp. 1985).

238. Id. \& $103(\mathrm{~h})(2)(\mathrm{C})$ (title, emphasis added).

239. Id. \& $103(\mathrm{~h})(2)(\mathrm{A}),(\mathrm{B})(\mathrm{i})$.

240. Id. \& $103(\mathrm{~h})(2)(\mathrm{B})(\mathrm{ii})$.

241. Id. \& $103(\mathrm{~h})(2)(\mathrm{C})$.

242. Id. \& $103(\mathrm{c})(2)$.

243. See Arkuss, supra note 25, at 17, col. 1. See generally H.R. REP. No. 432, Pt. II, 98th Cong., 2d Sess. 1679-80, reprinted in 1984 U.S. CODE CONG. \& AD. NEws No. 6B, 3, 607-08.

244. This provision is found in both House and Senate versions of the Act. H.R. ReP. No. 861, 98th Cong., 2d Sess. 1204, reprinted in 1984 U.S. Code Conc. \& AD. News No. 6B, 3, 751, 1198. 
nonguaranteed state and local government obligations. ${ }^{245}$ The result is that "the proliferation of such bonds may make it difficult for both the Federal and State governments to raise needed funds."246

There are a number of ways in which a bond payment may be guaranteed by the federal government or a federal agency, and several of these are explicitly excluded from the provisions of DEFRA section 622. Tax-exempt bonds financing student loans, for example, are federally guaranteed because the federal government insures repayment of the underlying loans; student loan bonds, however, are excluded from these provisions of the Act. ${ }^{247} \mathrm{~A}$ number of government agencies and quasi-agencies guarantee mortgages: some insure against default by the mortgagor, while others operate in the secondary mortgage market, buying up mortgages which they finance in part by issuing federally guaranteed debt; both types, in effect, provide insurance for repayment of any tax-exempt bonds which may have been issued to finance these mortgages. ${ }^{248}$ Guarantees by these organizations are also excepted, ${ }^{249}$ reflecting a congressional desire to preserve tax-exempt financing for mortgages which is also apparent in an explicit exception made for multifamily housing IDB's, public housing bonds, and qualified mortgage and veterans mortgage bonds. ${ }^{250}$ A similar exclusion is made for Small Business Administration (SBA) guarantees for pollution facility contracts, subject to a requirement that the SBA charge a fee which at least equals $1 \%$ of the amount guaranteed. ${ }^{251}$

Certain kinds of arbitrage are also permitted. Tax-exempt bond proceeds may be temporarily deposited in insured accounts or certificates of deposit "until such proceeds are needed for the purpose for which such issue was issued"'252 and, to the extent permitted under arbitrage regulations generally, may be used to purchase Treasury obligations. ${ }^{253}$ Exception is also provided for bond debt service funds and sinking funds. ${ }^{254}$ Loans to financial institutions, other than insured loans, are permitted despite the federal

245. H.R. ReP. No. 432, Pt. II, 98th Cong., 2d Sess. 1684-85, reprinted in 1984 U.S. Code CoNG. \&c AD. News No. 6B, 3, 613 .

246. Id. at 1685, reprinted in 1984 U.S. Code Cong. \& AD. News No. 6B, at 613.

247. I.R.C. $\$ 103(\mathrm{~h})(3)$ (A)(ii) (Lawyers Co-op. Supp. 1985).

248. These organizations include the Federal Housing Administration (FHA) and Veterans' Administration (V.A.), which guarantee mortgage repayment, and the Federal National Mortgage Corporation (Fannie Mae), the Federal Home Loan Mortgage Corporation (Freddie Mac), and the Government National Mortgage Association (Ginnie Mae), which assist in maintaining a secondary market for mortgages. See, e.g., R. Robinson \& D. Wrightsman, Financial Markets 337-40 (2d ed. 1980). The Student Loan Marketing Association (Sallie Mae) similarly assists in the secondary market for student loans. See generally H.R. REP. No. 432, Pt. II, 98th Cong., 2d Sess. 1679-82, reprinted in 1984 U.S. Code Conc. \& Ad. News No. 6B, 3, 608-11.

249. I.R.C. \& 10\$(h)(3)(A)(i)(ii) (Lawyers Co-op. Supp. 1985).

250. Id. $\$ 103(\mathrm{~h})(3)(\mathrm{C})$. This exception does not apply for obligations whose proceeds are invested in federally insured deposits or accounts. Id.

251. Id. $\& 103(\mathrm{~h})(3)(\mathrm{A})(\mathrm{iii})$. There is a further exception for outstanding guarantees by the Bonneville Power Authority for debt to be issued before July 1, 1989. Id. $\$ 103$ (h)(3)(A)(iv).

252. Id. \& $103(\mathrm{~h})(3)(\mathrm{B})(\mathrm{i})$.

253. Id. \& $103(\mathrm{~h})(3)(\mathrm{B})(\mathrm{iv})$.

254. Id. \& $103(\mathrm{~h})(3)(\mathrm{B})(\mathrm{ii})$-(iii). 
guarantee these institutions enjoy on deposits from other customers and despite the financial institutions' ability to invest the loan proceeds in Treasury obligations and other federally guaranteed securities. ${ }^{255}$

In light of the many minutely detailed provisions in this Title, one further exception is relatively remarkable in the broad discretion it confers on the IRS. Despite the general rule that tax-exempt bond proceeds may not be invested in federally guaranteed projects, tax exemption is retained for bonds whose proceeds are used to acquire "other investments permitted under regulations." 256

This discretion to make exceptions may well be needed, for there is potentially a very broad range of investments and other sources of tax-exempt bond repayment that are in some measure indirectly guaranteed by the federal government. Military presence in a community, for example, might lead to a contract for federal purchases from the local power company which could make the company ineligible for tax-exempt financing of its new pollution control equipment. Federal highway programs might jeopardize tax exemption of IDB's intended for construction of a bus station. Medicare payments could render impossible the use of tax-exempt IDB's to build a nursing home or upgrade a hospital. Similar scenarios are not difficult to imagine.

If these possibilities seem remote, there is at least one controversy which seems clearly at hand. It has long been contended by the IRS that the federal government cannot be a user of tax-exempt bond financed facilities. The basis for this position is the Public Debt Act of 1941,257 which mandated that all federal government obligations be taxable, combined with a theory that the federal government, as principal user of the facilities financed, was the "true obligor" of the tax-exempt obligations. ${ }^{258}$ The IRS position was rejected in 1981 by the Tax Court, and in 1982 by the District of Columbia Circuit, in Fairfax County Economic Development Authority $v$. Commissioner. ${ }^{259}$ The IRS has never officially abandoned its earlier position, however, and seems likely to revive it under the rubric of prohibiting tax-exempt financing where there is a federal guarantee. ${ }^{260}$

255. Id. \& 103(h)(3)(D).

256. Id. \& $103(\mathrm{~h})(3)(\mathrm{B})(\mathrm{v})$.

257. Public Debt Act of 1941, Pub. L. No. 77-7, \& 4, 55 Stat. 7, 9; see H.R. REP. No. 432, Pt. II, 98th Cong., 2d Sess. 1679, reprinted in 1984 U.S. Code Cong. \& AD. News No. 6B, 3, 608.

258. See Arkuss, supra note 25, at 17, col. 3.

259. 77 T.C. 546 (1981), affd, 679 F.2d 261 (D.C. Cir. 1982).

260. Cf. Arkuss, supra note 25 , at 17 , cols. 3-4. One argument against this outcome is that a federal guarantee must involve a secondary obligation supporting a separate primary obligation. "One possible solution to the problem may evolve in which obligations marketed on the credit of the United States are implicated under the Act while obligations sold without reference to federal government support would remain exempt." Id. at 17, cols. 4-18, col. 3. 


\section{V \\ Other IDB Regulations}

This section deals with a number of miscellaneous provisions in recent legislation which further restrict and regulate IDB's. Taken together, they can be expected to curtail some tax-exempt issuance, though the magnitude of this dampening effect would be difficult to determine. TEFRA contains three of these provisions. Section 215(a) requires public approval for tax-exempt IDB's, ${ }^{261}$ and section 219(a) limits their average length of maturity. ${ }^{262}$ Section 216(a) provides that accelerated depreciation methods may not be used for most facilities which are financed with tax-exempt IDB's; its scope is somewhat enlarged under DEFRA. ${ }^{263}$ (This last provision, possibly more than the other two, can be expected to effect some significant reduction in the use of IDB's to finance new capital construction.) There are explicit arbitrage provisions in DEFRA for IDB's and for student loan bonds. ${ }^{264}$ These measures contribute to the overall restrictive effect of DEFRA but are perhaps more remarkable for adding still more complexity to an already confusing area of the Code. Finally, recent legislation also contains incremental changes in the tax treatment of exempt-facilities IDB's, expanding somewhat the number of possible IDB issuers and uses, although none of these changes is likely to have a significant effect on overall tax-exempt debt.

\section{A. Public Approval Requirement}

For IDB's issued after 1982, tax exemption requires that the obligation receive public approval, either by a voter referendum or by a procedure described in some detail in the Act. ${ }^{265}$ Under the latter arrangement, the issue must be approved by an elected public official or legislative body of the governmental unit or units having jurisdiction over the area(s) where the financed facilities will be located. ${ }^{266}$ Prior to such approval, there must be reasonable public notice followed by a public hearing in each such area. ${ }^{267}$ An exception is made for obligations issued to refund bonds previously approved by one of these methods, as long as the maturity of the refunding issue does not exceed that of the refunded debt. ${ }^{268}$ Further exception is provided for bonds issued under a plan of financing which was previously

261. I.R.C. \$ 103(k) (Lawyers Co-op. 1984); see infra notes 265-72 and accompanying text.

262. I.R.C. $\$ 103$ (b)(14) (Lawyers Co-op. 1984); see infra notes 287-98 and accompanying text.

263. I.R.C. \& 168(f)(12) (Lawyers Co-op. 1984), amended by I.R.C. \$ 168(f)(12)(C) (Lawyers Coop. Supp. 1985); see infra notes $273-86$ and accompanying text.

264. I.R.C. \& 103(6) (Lawyers Co-op. Supp. 1985); Pub. L. No. 98-369, \& 625(a), 98 Stat. at $494-$ 95, reprinted in notes following I.R.C. $\$ 103$ (Lawyers Co-op. Supp. 1985); see infra notes 308-25 and accompanying text.

265. I.R.C. \& 103(k)(2)(B)(i), (ii) (Lawyers Co-op. 1984). If the governmental unit has no elected representative, approval must be given by an elected representative of the next higher level of government from which the unit derives its authority. Id. $\$ 103(\mathrm{k})(2)(\mathrm{E})(\mathrm{ii})$.

266. Id \& $103(\mathrm{k})(2)(\mathrm{A})$.

267. Id. $\$ 103(\mathrm{k})(2)(\mathrm{B})(\mathrm{i})$. For discussion of these procedural requirements, see generally Winston, supra note 110 , at $21-23$.

268. I.R.C. \& 103(k)(2)(D) (Lawyers Co-op. 1984). 
approved, as long as they are issued within three years after the date on which the first bonds were issued pursuant to that plan. ${ }^{269}$

It seems likely that this provision was intended to assist in preventing abuses in IDB use and in reducing the overall volume of IDB issuance. ${ }^{270}$ Because the process is cumbersome and involves additional expense, it should certainly have some deterrent effect. Whether the involvement of the general public will further impede debt issuance is, however, far from clear. Referendum requirements have previously been found somewhat effective as a deterrent to general obligation issues; ${ }^{271}$ however the popularity of projects designed to attract local industry and jobs may prove dispositive in many cases. ${ }^{272}$

\section{B. Restriction on Accelerated Depreciation}

The Accelerated Cost Recovery System (ACRS), as originally enacted in ERTA, ${ }^{273}$ provided a method of shortened recovery period and accelerated depreciation which significantly improved project profitability and encouraged new investment. ${ }^{274}$ As originally enacted, ACRS could be applied to projects financed with tax-exempt borrowing as well as to other new investment. Apparently concerned that this combination was unduly generous, Congress in TEFRA eliminated accelerated depreciation for most facilities financed by tax-exempt IDB's. ${ }^{275}$ Facilities are to be depreciated by the straight-line method, over the same length of time as would be used under ACRS or longer, at the option of the user. ${ }^{276}$

Exceptions to this rule were made for IDB's used to finance certain categories of facilities: low and moderate income rental housing, ${ }^{277}$ air or water pollution control facilities used in connection with a plant in operation before $1982^{278}$ or as part of converting such a facility from oil or gas firing to coal, ${ }^{279}$ local sewage and solid waste disposal facilities primarily serving the

269. Id. § $103(\mathrm{k})(2)(\mathrm{C})$.

270. Prior to TEFRA, a number of states imposed virtually no IDB approval requirements beyond mere formalities. See SMALl Issue, supra note 47, at 29-32. It has been suggested that voter approval requirements may serve as an effective procedural check against excessive or improper IDB issuance. E.g., Gelfand, Seeking Local Governmental Financial Integrity Through Debt Ceilings, Tax Limitations, and Expenditure Limits: The New York City Fiscal Crisis, The Taxpayers' Revolt, and Beyond, 63 MinN. L. Rev. $545,597-99$ (1979).

271. See, e.g., Advisory Comm'n on Intergovernmental Relations, State-Local finances: Significant FEATURES AND SUggested LEgislation 1972, at 149 (1972) (average voter approval percentage in bond elections around $60 \%$ during 1950-1970).

272. See, e.g., Winston, supra note 110 , at 23. There are, however, some known instances of voter resistance to new IDB financings in Montana, Alabama, and Oregon, and "[a] few localities" have refrained from authorizing IDB's to finance new retail stores because of opposition from established merchants in the community. SMall Issue, supra note 47 , at 30.

273. I.R.C. $\$ \S 167$ (a), 168 (Lawyers Co-op. Supp. 1985).

274. See, e.g., Hulten \& Wykoff, Economic Depreciation and Accelerated Depreciation: An Evaluation of the Conable-Jones 10-5-3 Proposal, 94 Nat'L TAX J. 45 (1981).

275. I.R.C. \& 168(f)(12) (Lawyers Co-op. Supp. 1985).

276. Id.

277. Id. \& $168(\mathrm{f})(12)(\mathrm{C})(\mathrm{i})$.

278. Id. \& $168(\mathrm{f})(12)(\mathrm{C})(\mathrm{iii})(\mathrm{I})$.

279. Id. \& $168(\mathrm{f})(12)(\mathrm{C})(\mathrm{iii})(\mathrm{II})$. 
general public, ${ }^{280}$ and facilities for which an urban development action grant (UDAG) had been made. ${ }^{281}$ Presumably these were felt to be unusually desirable investments which should receive maximum encouragement. DEFRA section 628(b), however, imposed straight-line depreciation on all but one of these categories, leaving in place only the exception for residential rental property financed by multifamily housing IDB's. ${ }^{282}$ Under DEFRA section 31 (a), ${ }^{283}$ moreover, the shortened ACRS depreciation period was no longer available for assets leased to governments or other tax-exempt entities. ${ }^{284}$ Such assets, if financed by IDB's, must now be depreciated straight-line over a longer period specified in DEFRA for "tax use property." 285

Denial of accelerated cost recovery for facilities financed by tax-exempt bonds forces a potential user of IDB financing to consider the tradeoff between the tax benefits of exemption, on the one hand, and those of accelerated depreciation, on the other. Preliminary indications are that in most instances the user will continue to use exempt financing. ${ }^{286}$ Whichever choice is made, however, the clear beneficiary of this provision is the federal government, whose tax loss is reduced from what it would have been under previous law, regardless of which option is selected.

\section{Maturity Limits}

For IDB's issued after 1982, bond interest is not tax-exempt if the average length of maturity of the issue exceeds the average expected economic life of the facilities financed by more than $20 \% .{ }^{287}$ Both average maturity and average economic life are calculated as weighted averages, with the weights based on relative cost of the various assets included as part of the financed facility. ${ }^{288}$ "Expected economic life" is determined in accordance with existing administrative guidelines (ADR midpoint lives), although the option is open to have it determined "on the basis of all the facts and circumstances" where special circumstances make the existing guidelines inappropriate. ${ }^{289}$ Land is ignored in the calculation unless its value is $25 \%$ or more of the cost of the project, in which case it is arbitrarily assigned a life of fifty years. ${ }^{290}$

\footnotetext{
280. Id. $\$ 168(\mathrm{f})(12)(\mathrm{C})(\mathrm{ii})(\mathrm{II})$.

281. Id. $\$ 168(\mathrm{f})(12)(\mathrm{C})(\mathrm{iv})$.

282. Id. $\$ 168(\mathrm{f})(12)(\mathrm{C})$.

283. Id. $\$ 168(\mathrm{j})$.

284. Id. \& $168(\mathrm{j})(2)(\mathrm{E})$.

285. The major difference appears to be a longer depreciation period for buildings which are "tax use property." See id.

286. A Congressional Research Service study released in January 1984, analyzing the effect on the demand for IDB financing of TEFRA provisions that reduced depreciation benefits for property financed with IDB's, concluded that "the TEFRA restrictions are likely to have very small effects on the demand for IDB financing." 22 TAx NotEs 355 (1984).

287. I.R.C. \& 103(b)(14)(A) (Lawyers Co-op. 1984).

288. Id. \& 103 (b)(14)(B)(i), (ii).

289. See id. \&103(b)(14)(B)(ii); Winston, supra note 110 , at 24 .

290. I.R.C. \& 103(b)(14)(C)(ii) (Lawyers Co-op. 1984).
} 
The legislative history does not give reasons for this TEFRA provision, but it seems consistent with the overall congressional intent to limit IDB financing. ${ }^{291}$ Ordinarily, financing with short-term debt is less expensive than long-term debt financing, ${ }^{292}$ and except in times of unusually high interest rates $^{293}$ there would seem to be little incentive for firms to prefer long-term IDB financing over debt whose maturity matched the expected life of the financed assets. Long-term debt is less risky to the borrower, however, since it need not be repaid so quickly. ${ }^{294}$ Moreover, in the case of IDB's, there is the additional advantage that in the later years of the bond's life, the firm will in effect enjoy tax-exempt financing for some of its general functions, since the financed facility has already spent its useful life and, presumably, repaid its original investment. By limiting the maturity of IDB's to $120 \%$ of the financed facility's expected life, TEFRA removed an obvious opportunity for abuse.

In effect, this measure serves as a supplement to the arbitrage bond provisions of the 1968 Act. ${ }^{295}$ Those provisions, described more fully in the next section, were designed to prevent the use of tax-exempt financing solely for financial gain based on arbitrage between low-cost, tax-exempt financing and higher-yielding, "taxable" securities. ${ }^{296}$ While the chief targets of arbitrage regulations have been sinking funds ${ }^{297}$ and refunding issues, ${ }^{298}$ the issuance of tax-exempt debt which is expected to remain outstanding after the facility it finances is no longer useful seems also to be a form of arbitrage, or at least analogous to it. The TEFRA provision, accordingly, seems a logical extension of existing law in this regard.

\section{Arbitrage Regulations}

A number of the recent enactments ${ }^{299}$ pertaining to municipal bonds are aimed at preventing abuse from arbitrage by issuers that borrow at low taxexempt rates in order to reinvest at the higher yields available on taxable

291. The provision originated in the Senate but is not mentioned in the Senate Report. The House Conference Report states only that "[p]resent law is unclear on the length of time that bonds may be outstanding in relation to the economic life of the property financed with tax-exempt financing." H.R. ReP. No. 760, 97th Cong., 2d Sess. 515, reprinted in 1982 U.S. Code Cong. \& AD. NEws 1190,1291 . Since prior to TEFRA the term of IDB financings usually was less than or equal to the useful lives of the financed facilities, there may be no immediately discernible effect of this provision on the volume or average maturity of IDB issues. See Winston, supra note 110, at 24.

292. See, e.g., J. Weston \& E. Brigham, Managerial Finance 271-80 (7th ed. 1981). See generally J. Michaelsen, The Term Structure of Interest Rates ch. 4 (1973) (and sources cited therein).

293. When short-term interest rates are generally expected to fall, long-term rates may be lower than those on short-term obligations. See, e.g., J. Van Horne, Function and Analysis of Capital. MARKET RATES ch. 4 (1970).

294. E.g., J. Weston \& E. BRigham, supra note 292, at 280.

295. I.R.C. \& 103(c) (Lawyers Co-op. 1984).

296. See Washington v. Commissioner, 692 F.2d 128, 133-35 (D.C. Cir. 1982).

297. See Tucson v. Commissioner, 78 T.C. 767 (1982) (upholding validity of Treas. Reg. $\$ 1.103$ 13(g)(1), (2), which provides that amounts held in a sinking fund for a bond issue are treated as proceeds of the issue and come under the arbitrage provisions of I.R.C. \& 103(c)).

298. See generally Mumford, Arbitrage and Advance Refunding, 1976 DukE L.J. 1239.

299. See, e.g., supra text accompanying notes 222-36 (consumer loan bonds), 287-98 (maturity limits), 237-61 (federal government guarantees); see especially notes $242-44$ and accompanying text. 
securities or other investments. Arbitrage transactions are not self-limiting, either in amount or frequency. ${ }^{300}$ Unchecked, they could pose a serious threat to any attempt to curtail the market displacement and lost Treasury revenue associated with increased volume of tax-exempt borrowing. Accordingly, recent legislation in this area is logically consistent with volume limitation of private activity bonds, already discussed. ${ }^{301}$ It should be noted, however, that arbitrage regulations are by no means limited to private activity bonds. Indeed, it is state and local govenments which would stand to gain the most from unregulated arbitrage transactions, because income they receive from higher-yielding "taxable" investments would also be sheltered from tax.

The basic Code provision designed to discourage arbitrage is contained in section 103(c). It denies exemption to "arbitrage bonds," defined generally as obligations used to acquire higher-yielding ${ }^{302}$ securities or to replace funds which were used directly or indirectly to acquire such securities.303 Exceptions are made for bond proceeds invested temporarily until needed for their intended purpose $\mathrm{e}^{304}$ and for securities or other obligations acquired to be part of a "reasonably required reserve or replacement fund." 305 Treasury regulations for this section are complex, ${ }^{306}$ and interpretation of these provisions has tended to be extremely difficult, particularly with regard to refunding issues. ${ }^{307}$

Into this morass of regulation, DEFRA introduces new complexity for private activity bond issues. ${ }^{308}$ Section 624 of the Act restricts investment of IDB proceeds in "non-purpose" obligations (NPO's),, 309 securities or other "taxable" obligations which are acquired with the gross proceeds of an issue for a purpose other than to carry out the "governmental purpose of the issue." 310 An exception is made for public housing bonds 311 and IDB's financing multifamily residential rental projects. ${ }^{312}$ Section 625 empowers the Secretary of the Treasury at his discretion to impose the requirements of section 624 on student loan bonds as well. ${ }^{313}$ Section 625 also calls for a

300. Peaslee, The Limits of Section 103(c): Municipal Bond Arbitrage After the Invested Sinking Fund, 34 TAX L. REV. 423, 424 (1979).

301. Supra text accompanying notes 168-99.

302. This rule applies when yields on acquired bonds are "materially higher," which in most cases means more than $0.125 \%$ higher. Treas. Reg. \& 1.103-13 (1979); $c$. H.R. REP. No. 432, Pt. II, 98th Cong., 2d Sess. 1199-1200.

303. I.R.C. \$ 103(c)(2) (Lawyers Co-op. 1984).

304. Id. $\$ 103(\mathrm{c})(4)(\mathrm{A})$.

305. Id. $\$ 103(\mathrm{c})(4)(\mathrm{B})$.

306. Treas. Reg. \& 1.103-13 (1979).

307. See, e.g., Peaslee, supra note 300.

308. "For those who have labored in the arbitrage vineyards of the pre-existing regulations, the notion of another layer of complexity may seem incredible." Arkuss, supra note 25, at 16, cols. 3-4.

309. I.R.C. \& 103(c)(6)(A), (C) (Lawyers Co-op. Supp. 1985).

310. Id. $\$ 103(\mathrm{c})(6)(\mathrm{H})$.

311. Id. $103(\mathrm{c})(6)(\mathrm{B})$ (bonds authorized under section 11(b) of the Housing Act of 1937).

312. Id.

313. Pub. L. No. 98-369, \& 625(a)(1), (3)(B), 98 Stat. 494, 924-25, reprinted in notes following I.R.C. \& 103 (Lawyers Co-op. Supp. 1985). This option applies to "qualified" student loan bonds, as defined in new Code \& $103(\mathrm{o})(3)$, id \& $825(\mathrm{a})(2)(\mathrm{A}), 98$ Stat. at 924, reprinted in notes following I.R.C. 8103 (Lawyers Co-op. Supp. 1985). For nonqualified bonds, arbitrage regulations will apply after 
Congressional Budget Office study of student loan bonds, including "the appropriate arbitrage rules for such bonds." 314

Under section 624, investment in NPO's is inhibited in two ways: (1) there is a rebate to the United States of arbitrage profits on such investment, ${ }^{315}$ and (2) there is a limit placed on the amount of issue proceeds which may be invested in NPO's. ${ }^{316}$ This latter requirement is apparently superfluous, in that full disgorgement of profits presumably removes all incentive for abuse, ${ }^{317}$ but it is nonetheless dangerous for the issuer and subsequent bondholders, since the penalty for noncompliance is loss of tax exemption for the IDB issue. The limit is calculated with respect to debt service on the issue-at no time during any bond year may the amount invested in NPO's whose yield exceeds the yield of the IDB issue be more than $150 \%$ of the debt service for that year-and is supplemented by a requirement that investment in NPO's be "promptly and appropriately reduced as the amount of outstanding obligations of the issue is reduced." 318 Difficulties of interpretation seem inevitable.

The rebate requirement is somewhat more susceptible of smooth application, despite potentially tricky yield calculation problems. ${ }^{319}$ Issuers will actually be penalized by the rebate, since IDB "yield" is calculated for this section without regard to flotation costs and other costs of issuance. ${ }^{320}$ There are two safe harbors. Earnings of a small "bona fide debt service fund" may be ignored at the issuer's option. ${ }^{321}$ Also, no rebate is required when the "gross proceeds" of an issue-including income from investing the original issue proceeds and debt service already paid out on the issue ${ }^{322}$-are expended for the governmental purpose within six months after the date of issuance. ${ }^{323}$ This latter exception will presumably encourage issuers to delay financing until shortly before expenditure is anticipated. ${ }^{\mathbf{3 2 4}}$

December 31, 1985. Id. $\$$ 625(b), 98 Stat. at 925, reprinted in notes following I.R.C. $\S 103$ (Lawyers Co-op. Supp. 1985).

314. Id. § 625(e)(1), 98 Stat. at 925-26, reprinted in notes following I.R.C. § 103 (Lawyers Co-op. Supp. 1985).

315. I.R.C. \& 106(c)(6)(D) (Lawyers Co-op. Supp. 1985).

316. Id. \& 106(c)(6)(C).

317. Cf. Arkuss, supra note 25 , at 17 , col. 1 (since all excess arbitrage is rebated, the reason for the investment limitation "remains a mystery"). Actually, the rebate is a disincentive, see infra note $\mathbf{3 2 0}$.

318. I.R.C. $\$ 103(\mathrm{c})(6)$ (C)(I)-(II) (Lawyers Co-op. Supp. 1985).

319. Proposed (and temporary) regulations already deal with one of the potential problems, that of computing yield on variable rate issues. Proposed Treas. Reg. \& 1.103-15AT(c)(4); of. Arkuss, supra note 25, at 17, col. 1 (anticipates these regulations).

320. Yields on IDB's are calculated for this purpose without adjusting gross issue proceeds for costs associated with marketing the issue. I.R.C. \$ 103(c)(6)(H)(iii) (Lawyers Co-op. Supp. 1985). The result is that IDB yields are estimated to be lower than the effective rate to the issuer on proceeds it receives. Disgorgement of all arbitrage profits by this calculation would, accordingly, force an issuer to "swallow" his transaction costs.

321. Id. \& $103(\mathrm{c})(6)(\mathrm{F})(\mathrm{II})$.

322. Id. \& $103(\mathrm{c})(6)(\mathrm{H})(\mathrm{ii})$.

323. Id. \& 103 (c)(6)(C)(ii), (F)(ii).

324. "Staged financing for separate phases of a particular project may become a popular method for dealing with this situation." Arkuss, supra note 25, at 17, col. 1 . 
It should be noted that these new arbitrage regulations apply only to private activity bonds. No rebate of arbitrage profits to the federal government is required of state and local governments and authorities. However, DEFRA leaves in place all previous arbitrage regulation, so states as well as other borrowers stand to lose tax exemption of their bonds when a substantial portion of the issue is invested in higher-yielding investment. ${ }^{325}$ The chief change made by DEFRA for private activity bonds, in addition to the rebate requirement, is in providing what is, in effect, a definition of "substantial portion," calculated both with respect to the volume of outstanding debt and, with some precision, with respect to the current debt service on the issue.

\section{E. Exempt-Facility IDB's}

By contrast to the dramatic changes in small issue tax treatment, recent legislation directly concerned with exempt-facility IDB's has been limited in scope and interstitial in nature; it seems unlikely to have more than a very minor impact on the overall volume of tax-exempt borrowing. ${ }^{326}$ The measures enacted for the most part seem fully consistent with previous legislation in this area, and whatever shift they may reflect in political philosophy or preference is not readily apparent. One of these measures, which creates a new category of exempt-purpose borrowing, was enacted in ERTA and is a plausible extension of another provision of that Act. ${ }^{\mathbf{2 2 7}}$ Provisions in TEFRA create one new category of exempt facility and provide a somewhat wider range of application for several others. ${ }^{328}$ DEFRA makes no remarkable changes in this area.

1. Leased Mass Commuting Facilities. One major feature of ERTA was its "safe harbor leasing" provision, section 201 (a), ${ }^{329}$ which guaranteed that certain transactions between a nominal corporate lessor ${ }^{330}$ and a lessee of new property that qualifies for investment tax credit would be characterized as a lease for the purpose of allowing investment credits and (accelerated) capital cost recovery allowances to the nominal lessor. ${ }^{331}$ ERTA section 811 permitted tax exempt financing, for a limited period, for "mass commuting

325. I.R.C. \& 103(c)(1) (Lawyers Co-op. Supp. 1985).

326. See, e.g., Winston, supra note 110 , at 27.

327. I.R.C. $\$ 103(\mathrm{~b})(4)(\mathrm{I}),(9)$ (Lawyers Co-op. 1984); see supra note 33 and accompanying text.

328. I.R.C. \& 103(b)(4), (10)(B)(ii) (Lawyers Co-op. 1984); see infra notes 334-61 and accompanying text.

329. I.R.C. $\$ 168$ (as amended) (Lawyers Co-op. Supp. 1985).

330. The lessor must be a corporation other than a tax-option small business corporation or personal holding company (or a partnership of, or grantor trust for the benefit of, such corporations). Id. \& $168(\mathrm{f})(8)(\mathrm{B})(\mathrm{i})$.

331. The provisions apply to new recovery property leased within three months after it is put in service, for less than a specified maximum lease term. The lessor must have a minimum at-risk investment. See id. \& 168(f)(8)(A), (B)(ii)-(iii), (D), (E).

TEFRA removed most ACRS and investment credit benefits for "safe harbor" leased property. See I.R.C. \& 168(i) (Lawyer's Co-op. Supp. 1985); Pub. L. No. 97-248, \& 208(c), 96 Stat. at 439, reprinted in notes following I.R.C. \& 168 (Lawyer's Co-op. Supp. 1985). However, the TEFRA modifications do not apply in the case of a mass commuting vehicle placed in service before January 
vehicles such as buses, subway cars, rail cars or similar equipment leased to a mass transit system wholly owned by 1 or more governmental units (or agencies or instrumentalities thereof), and ... used by such system in providing mass commuting services." 332 Noting that the nation's supply of mass commuter vehicles was dangerously depleted and dilapidated, the House Ways and Means Committee expressed its hope that the measure would attract private capital as a supplement to government-financed improvements and replacements. ${ }^{333}$

2. Local District Heating and Cooling Facilities. TEFRA section 217(a), amending Code section 103(b)(4), adds a new category of exempt-purpose facility for which tax-exempt IDB's may be issued. ${ }^{334}$ These are "local district heating or cooling facilities," defined as "property used as an integral part of a local district heating or cooling system." 335 The term "local district heating or cooling system" means any facility "furnishing heating and cooling to an area consisting of a city and one contiguous county" 336 which comprises

. . . a pipeline or network (which may be connected to a heating or cooling source) providing hot water, chilled water, or steam to 2 or more users for-

(I) residential, commercial, or industrial heating or cooling, or

(II) process steam. ${ }^{337}$

This measure was explained in the Senate Report as a logically consistent corollary to existing exemptions for IDB's issued to finance facilities for local furnishing of gas or electricity. ${ }^{338}$ It seems evident that the major employment of these facilities will be for commercial and industrial purposes, particularly since the number of users need be no more than two. ${ }^{339}$ Industrial use is not necessarily incompatible with the public purpose test applied to exempt-purpose bonds, and IDB's used to provide gas or electric power to industry have been found to meet this test. ${ }^{340}$ Thus, while this measure may seem to be particularly designed as an aid to industry rather

1, 1988. Id. $\$ 208$ (d), 96 Stat. at 440-41, reprinted in notes following I.R.C. $\$ 168$ (Lawyer's Co-op. Supp. 1985).

332. I.R.C. $\S 103(b)(4)(I),(9)$ (Lawyers Co-op. 1984).

333. H.R. REP. No. 201, 97th Cong., 1st Sess. 269 (1981). The provision was amended in TEFRA to include ferries in this category of "qualified mass commuting vehicles." I.R.C. $\S 103(b)(9)(A)$ (Lawyers Co-op. 1984). The provision may have been somewhat redundant inasmuch as proposed Treasury Regulations already defined "similar equipment" (in the original act) to include "a ferry vessel." See 46 Fed. Reg. 63,326 (1981) (to be codified at 26 C.F.R. \& 1.103-8(i)) (proposed Dec. 31, 1981); $q$. Jamestown \& Newport Ferry Co. v. Commissioner, 41 F.2d 920, 923 (1st Cir. 1930) ("All ferries are, in general, regarded as publici juris.").

334. I.R.C. \& 103(b)(4)(J) (Lawyers Co-op. 1984).

335. Id. \& $103(\mathrm{~b})(10)(\mathrm{A})$.

336. Id. \& 103(b)(10)(B)(ii); see infra notes $342-43$ and accompanying text (discussion of "two contiguous county" and "one city, one county" rules).

337. I.R.C. \& 103(b)(10)(B)(i) (Lawyers Co-op. 1984).

338. S. Rep. No. 494, 97 th Cong., 2d Sess. 178, reprinted in 1982 U.S. Code Cong. \& AD. News $781,939$.

339. See I.R.C. \& 103(b)(10)(B)(i) (Lawyers Co-op. 1984).

340. E.g., Letter Rul. 8220049 (Feb. 17, 1982); see Treas. Reg. $\$ 1.103-8(a)$ (2) (1972) (a facility serving a single nonexempt person may still meet the public use requirement if that nonexempt person directly serves the general public"; see also id. \$ 1.103-8(f). 
than to the general public, it is not entirely inconsistent with prior existing legislation.

\section{Territorial Expansion.}

a. Local gas facilities. The 1968 Act conferred exempt-purpose status on IDB's used to finance "sewage or solid waste disposal facilities or facilities for the local furnishing of electric energy or gas." 341 The word "local" is not defined in the Act, nor is it explained or defined in the accompanying legislative reports. Treasury regulations interpreted it as referring to facilities which are part of a system "providing service to the general populace in a service area comprising no more than two contiguous counties." 342 In the Revenue Act of 1978, however, the definition was modified for electrical systems to include those which provided energy to the population of a service area comprising no more than a city and one contiguous county. ${ }^{343}$ TEFRA section 217(b) expanded this definition of "local" to cover facilities for the local furnishing of gas. ${ }^{344}$

b. Regional pollution authorities. Code section 103(b)(4)(F) provides exemption for bonds used to finance "air or water pollution control facilities," 345 and in TEFRA section 217(d) this exempt purpose category was extended to include bonds "used by a qualified regional pollution control authority to acquire existing air or water pollution control facilities which the authority itself will operate in order to maintain or improve the control of pollutants." 346 For the regional authority bonds to be tax-exempt, the amount paid for the facilities may not exceed their fair market value, ${ }^{\mathbf{3 4 7}}$ the fees charged the seller after the sale may not be less than would be charged if the facility were financed with taxable obligations, ${ }^{348}$ and "no person other than the qualified regional pollution control authority [may be] considered

341. I.R.C. \& 103(b)(4)(E) (Lawyers Co-op. 1984).

342. Treas. Reg. \& 1.103-8(f)(2)(iii) (1972).

343. I.R.C. \& 103 (b)(4) (Lawyers Co-op. 1984). The accompanying Conference Report stresses the conferees' intent to make the "one city, one county" alternative an exception from the general "two contiguous counties" rule consistent with the requirement of the original act. H.R. REP. No. 1800, 95th Cong., 2d Sess. 239, reprinted in 1978 U.S. Code Cong. \& AD. NEws 7198, 7239-40.

344. I.R.C. \& 103(b)(4) (Lawyers Co-op. 1984). "The [Senate] committee concluded that the same reasons that the Congress had in 1978 for extending the local furnishing of electricity to a service area consisting of no more than a city and a contiguous county also apply in the case of the local furnishing of gas." S. REP. No. 494, 97th Cong., 2d Sess. 176, reprinted in 1982 U.S. CodE Conc. \& AD. News 781, 938. A similar definition is built into the new provision for local heating and cooling facility IDB's in TEFRA section 217(a). See I.R.C. \& 103(b)(10)(B)(ii) (Lawyers Co-op. 1984).

345. I.R.C. \& 103(b)(4)(F) (Lawyers Co-op. 1984).

346. Id. \& $103(\mathrm{~b})(11)(\mathrm{A})$. A "qualified regional pollution control authority" is defined as one which

(i) is a political subdivision created by State law to control air or water pollution;

(ii) has within its jurisdictional boundaries all or part of at least two counties (or equivalent political subdivisions); and

(iii) operates air or water pollution control facilities.

Id. 8108 (b)(11)(C).

347. Id \& $103(\mathrm{~b})(11)(\mathrm{B})(\mathrm{i})$.

348. Id \& 103(b)(11)(B)(ii). 
after the sale as the owner of the facilities for purposes of Federal income taxes." 349

4. Residential Rental Property. The 1968 Act provided an exempt purpose exemption for IDB's used to provide "residential real property for family units," 350 an exemption which continued in force until 1980, when it was amended by the Mortgage Subsidy Bond Tax Act of 1980.351 The 1980 Act established a new exempt category of bonds issued to finance "single family residences which can reasonably be expected to become the principal residences of the mortgagors," 352 providing for them separately under Code section 103A. Remaining exempt under Code section 103(b)(4) were IDB's used to provide projects for residential rental property, subject to new qualifications that at all times during the "qualified project period"

(i) 15 percent or more in the case of targeted area projects, or

(ii) 20 percent or more in the case of any other project, of the units in each project are to be occupied by individuals of low or moderate income. ${ }^{353}$

"Targeted area projects" qualifying for the lower required percentage were defined as those located in census tracts "in which $70 \%$ or more of the families have income which is eighty percent or less of the statewide median family income" or which were designated by the state, with the concurrence of the Secretaries of Treasury and Housing and Urban Development, as areas "of chronic economic distress." 354

TEFRA made two changes in the legislation which provides exemption for these rental property bonds. First, under previous law the "qualified project period," during which $20 \%$ (or $15 \%$ ) of the units must be occupied by persons of low or moderate income, extended for a period of twenty years. ${ }^{355}$ TEFRA reduced this figure, by providing that the period ends at the later of

(i) the date which is 10 years after the date on which 50 percent of the units in the project are occupied,

(ii) the date which is a qualified number of days [equal to half the maturity of the bond issue] after the date on which any of the units in the project are occupied, or

(iii) the date on which any assistance provided with respect to the project under section 8 of the United States Housing Act of 1937 terminates. ${ }^{356}$

349. Id. § 108(b)(11)(B)(iii).

350. Revenue and Expenditure Control Act of 1968, Pub. L. No. 90-364, § 107(a), 82 Stat. 251, 266.

351. Mortgage Subsidy Bond Tax Act of 1980, Pub. L. No. 96-499, 94 Stat. 2660.

352. I.R.C. \& 103A(a), (d)(1)(A) (Lawyers Co-op. 1984); see H.R. ReP. No. 1167, 96th Cong., 2d

Sess. 356, reprinted in 1980 U.S. CODE Conc. \& AD. NEws 5526, 5720.

353. I.R.C. \& 103(b)(4)(A) (Lawyers Co-op. 1984).

354. Id. $8103 \mathrm{~A}(\mathrm{k})$.

355. See H.R. Conf. ReP. No. 97-760, 97th Cong., 2d Sess. 524, reprinted in 1982 U.S. Code Cong. \& AD. News $1190,1299$.

356. I.R.C. \& 103(b)(12)(B) (Lawyers Co-op. 1984). 
Second, TEFRA defined "low or moderate income" to be income at or below $80 \%$ of median gross income for the area. ${ }^{957}$ Previously this determination had been left to the Secretary of the Treasury. ${ }^{358}$

The shortening of the qualified project period in TEFRA may be thought to detract from the exempt-facility exemption's apparent goal of helping to provide adequate housing to the poor. The effect, however, might be to increase, rather than decrease, the supply of low income housing, if the provision were to make residential rental property more attractive to prospective investors. On balance, it seems unlikely that the measure will have much discernible effect on the supply of rental housing for the poor.

It should be noted, however, that DEFRA, though it makes no major changes in the tax treatment of residential rental property, may cause such property to become relatively much more attractive to potential investors. This result may be expected from the fact that bonds financing residential rental property, more than any other category of IDB, are exempt from the bulk of restrictive provisions enacted in DEFRA for other forms of IDB financing. ${ }^{359}$

5. New IDB Issuers. Two new categories of users are authorized to issue taxexempt bonds under recent legislation, and a third is authorized to lease facilities financed by the owner with tax-exempt debt. This extension of authority for tax-exempt borrowing, however, is extremely limited. Section 812 of ERTA extends exemption to obligations issued by volunteer fire departments after 1980 to finance firehouses and firetrucks. ${ }^{360}$ Section 629 (b) of DEFRA authorizes railroads to use small issues to acquire railroad track and right-of-way from a bankrupt railroad, when the Federal Railroad Administration provides joint financing. ${ }^{361}$ DEFRA also adds public utilities to the categories of "exempt persons" eligible to lease facilities and equipment whose acquisition by the lessor was financed with tax-exempt IDB's. ${ }^{362}$

357. Id. $\$ 103(\mathrm{~b})(12)(\mathrm{C})$.

358. See id.

359. Most notably, these bonds are exempt from the DEFRA volume cap, see supra notes 170-71 and accompanying text. They are also excepted from provisions regarding federal government guarantees, see supra note 250 and accompanying text, advance refunding, see supra note 181 , and straight-line depreciation, see supra notes 277-82 and accompanying text.

360. I.R.C. \& 103(i) (Lawyers Co-op. 1984). The fire department must provide firefighting or emergency medical services to persons not otherwise provided with these services, and it must be under written contract to provide the services. Id. \& 103(i); see Treas. Reg. \$1.103-16 (1983).

A special exception for one obligation issued to the First Bank and Trust Company of Indianapolis before 1980, see Economic Recovery Tax Act of 1981, Pub. L. No. 97-34, § 812(b)(2)(B), 95 Stat. 175, 350, suggests that this provision may have originated in response to a particular situation, though it was fully considered by both House and Senate Committees and the Conference Committee before passage. See H.R. REP. No. 215, 97th Cong., 1st Sess. 270, reprinted in 1981 U.S. Code Cong. \& AD. News 285, 358-59.

361. Deficit Reduction Act of 1984, Pub. L. No. 98-369, 8 629(b), 98 Stat. 494, 939, reprinted in notes following I.R.C. \& 103 (Lawyers Co-op. Supp. 1985).

362. Id. \& 629(a), (c), 98 Stat. at 932-33, reprinted in notes following I.R.C. \& 103 (Lawyers Co-op. Supp. 1985). 
None of these changes is likely to effect a measurable increase in the volume of tax-exempt IDB's. In this regard, it is interesting to note that 1983 legislation which provides Indian tribal governments with the status of states for a variety of purposes, including issuance of tax-exempt debt to finance governmental services, ${ }^{363}$ carefully excludes the right to issue tax-exempt IDB's, mortgage subsidy bonds, or scholarship bonds. ${ }^{364}$ Bonds issued by Indian tribes are to be tax-exempt "only if such obligation is part of an issue substantially all of the proceeds of which are to be used in the exercise of any essential governmental function." 365

\section{VI \\ Registered Form Requirement}

The one provision of recent municipal bond tax legislation which applies to all forms of municipal bonds, including revenue bonds and general obligations, may prove in the long run the most memorable. This is a provision, in TEFRA, that "[n]othing in subsection (a) or in any other provision of law shall be construed to provide an exemption from Federal income tax for interest on any registration-required obligation unless the obligation is in registered form." 366 "Registration-required obligations" are bonds "of a type offered to the public," 367 with a maturity in excess of one year. ${ }^{368}$ An obligation is in registered form if "the right to principal of, and stated interest on, such obligation may be transfered only through a book entry consistent with regulations" issued by the Treasury. ${ }^{369}$ In case of noncompliance, interest on the bonds is taxable to the bondholders; moreover, the user forfeits his deduction for the interest expense incurred. ${ }^{370}$

The "registered-form" requirement is clearly designed to prevent laundering and tax evasion through the use of unregistered, unreported, taxexempt coupon bonds. However, the controversy surrounding the provision is unrelated to its purpose. The requirement is the subject of a suit by the state of South Carolina, which seeks to enjoin its application to general obligations on constitutional grounds. ${ }^{371}$ On February 23, 1984, the Supreme Court agreed to submit to a master, for later decision by the Court,

363. I.R.C. \& 7871(a)(4) (Lawyers Co-op. Supp. 1985).

364. Id. \& $7871(\mathrm{c})(2)$.

365. Id. \& $7871(\mathrm{c})(1)$.

366. Id. \& 103(j)(1) (Lawyers Co-op. 1984).

367. Id. \& $103(\mathrm{j})(2)(\mathrm{A})$.

368. Id. \& $103(\mathrm{j})(2)(\mathrm{B})$.

369. Id. \& 103(j)(3)(A). Temporary Regulation \& 5f.103-1(c)(1) provides that:

An obligation is in registered form if-

(i) The obligation is registered as to both principal and any stated interest and transfer of the obligation may be effected only by the surrender of the old instrument and either the reissuance by the issuer of the old instrument to the new holder or the issuance by the issuer of a new instrument to the new holder, or

(ii) The right to the principal of, and stated interest on, the obligation may be transferred only through a book entry system (as described in paragraph (c)(2) of this section).

370. I.R.C. \& 6049(b)(1)(A)(i) (Lawyers Co-op. Supp. 1985).

371. South Carolina v. Regan, 465 U.S. 367 (1984). 
the question whether tax exemption of state and local government obligations is constitutionally mandated. ${ }^{372}$

The question whether or not general obligation municipal debt may constitutionally be taxed by the federal government has not come directly before the Court since passage of the sixteenth amendment empowering Congress to tax income "from whatever source derived." "373 A thorough analysis of the issues involved is beyond the scope of this note. It should be noted, however, that Supreme Court resolution of the issues raised in South Carolina's suit may provide at last a definitive answer to an old and longdebated controversy.

\section{VII}

\section{Conclusions}

There is a lot of picky detail in recent municipal bond tax legislation. Many provisions seem unnecessarily complicated, and a number seem to be ad hoc responses to particular situations rather than integral parts of a wellplanned whole. Transitional rules and individual exceptions abound, particularly in DEFRA. ${ }^{974}$ Yet, beyond the smokescreen of detail and complexity, this is important legislation, accomplishing major change in an area many critics have long considered ripe for reform.

Clearly the most important thrust of the legislation is aimed at limiting the volume of tax-exempt debt outstanding, primarily by reducing the volume of new IDB borrowing. While the small issue sunset and more recently enacted volume caps are primary instruments of this effect, they are supplemented by other provisions which will also tend to inhibit or restrict the use of IDB debt. New categories of borrowing ineligible for tax-exempt financing, reporting and public approval requirements which add to the cost of issuing new debt, unfavorable depreciation treatment compared to that available for non-IDBfinanced projects, and new limits on the length of maturity of issues all contribute to reduced issuance of IDB's, especially, and thus to the overall goal of reduction in the volume of tax-exempt obligations generally.

Several results can be expected from this reduction in the volume of taxexempt debt. First, and most obvious, is an increase in the level of federal government tax revenues. Second, it is reasonable to expect lower yields on remaining tax-exempt bonds, as buyers seeking tax-exempt securities bid up their prices, with a concomitant reduction in borrowing costs for the issuers of these bonds. The extent to which tax-exempt yields will remain reduced depends in part on the extent to which issuers of securities retaining the tax exemption respond to lower borrowing costs by increasing their levels of

372. Id. at 425 .

373. U.S. CoNST. amend. XVI. For a history of intergovernmental taxation immunity, see South Carolina v. Regan, 465 U.S. 367, 404-17 (1984) (Stevens, J., partially concurring).

374. "It was necessary to have liberal transition rules to accommodate most concerns of individual members when making so significant a change, and these rules are provided." 130 CoNG. REc. H7086 (June 27, 1984) (remarks of Rep. Rostenkowski). 
capital financing and debt. However, the presence of volume caps to deter such increases in private activity borrowing, and a well-established pattern of inelasticity in the supply of revenue bonds and general obligation debt, make it unlikely that yields would be driven back up to any great extent.

As prices are bid up on new tax-exempt issues, two further effects can be expected. Those potential purchasers in the lowest tax brackets, having less to gain from tax exemption, will drop out of the competition, leaving the marginal tax bracket of the new "marginal" buyer higher than before. For bondholders in any given bracket, the benefits of tax exemption will be reduced. Put differently, ownership of tax-exempt bonds will be increasingly restricted to the rich, and they will be receiving lower yields on their taxexempt investment.

Decreased supply of tax-exempt municipals will thus promote both vertical and horizontal equity. Those subject to tax at high rates will gain relatively less from exemption and will thus enjoy less advantage over those subject to lower rates whose investment income is taxed. Put differently, the marginal tax bracket of the marginal municipals buyer will rise, reducing the "surplus" benefit which exemption affords to those whose tax bracket is higher. Moreover, as wealthy holders of municipals experience reduced benefits from tax exemption, they will lose their relative advantage over others similarly situated who own no tax-exempt securities. The result is an increase in horizontal equity-equal treatment of equals-as well as an increase in the effective progressivity of the federal tax structure.

With the exception of increased federal tax revenues, all these effects depend on the assumption that yields on municipal bonds will be reduced by these measures through increased competition for the reduced supply of available tax-exempt bonds. While it seems clear that the supply of municipals is indeed likely to be reduced by the recent tax legislation, it is by no means certain that municipals' yields will, in fact, fall. The reason lies in the probable effect which other tax legislation, beyond the scope of this note, will have on the demand for tax-exempt bonds. Reduced tax rates both for individuals and for corporations-private tax shelters such as IRA's and corporate ones such as safe harbor leasing-have all made tax-exempt bonds relatively less attractive when compared to alternative investments. Reduced demand would, of course, drive municipals' yields up. The result would counter the generally desirable effects of reduced supply in enhancing tax progressivity and horizontal equity and in making public projects less expensive for state and local governments to undertake. 